\title{
Identification, Characterization, and Analysis of Hydraulically Conductive Fractures in Granitic Basement Rocks, Millville, Massachusetts
}

by F.L. Paillet' ${ }^{1}$ and Paul Ollila ${ }^{2}$

U.S. GEOLOGICAL SURVEY

Water-Resources Investigations Report 94-4185

${ }^{1}$ U.S. Geological Survey, Denver, Colorado

${ }^{2}$ Massachusetts Dept. of Environmental Protection, Worcester, Massachusetts 


\section{U.S. DEPARTMENT OF THE INTERIOR \\ BRUCE BABBITT, Secretary}

U.S. GEOLOGICAL SURVEY

Gordon P. Eaton, Director

The use of trade, product, industry, or firm names is for descriptive purposes only and does not imply endorsement by the U.S. Government.

For additional information write to:

Copies of this report can be purchased from:

Chief, Branch of Regional Research

U.S. Geological Survey

U.S. Geological Survey

Earth Science Information Center

Box 25046, MS 418

Open-File Reports Section

Denver Federal Center

Box 25286, MS 517

Denver, CO 80225

Denver Federal Center

Denver, CO 80225 


\section{CONTENTS}

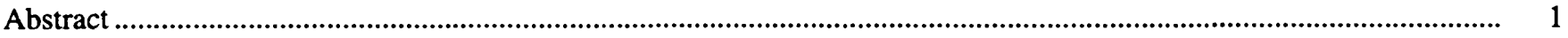

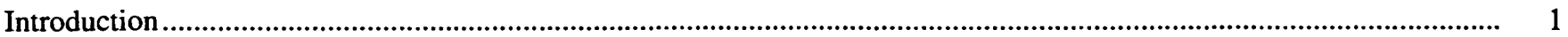

Purpose and scope

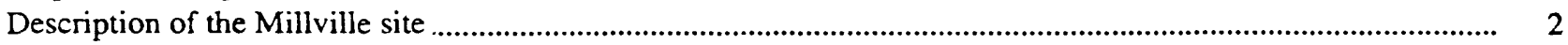

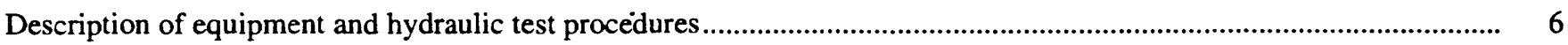

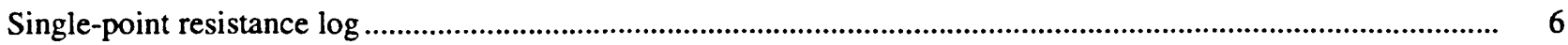

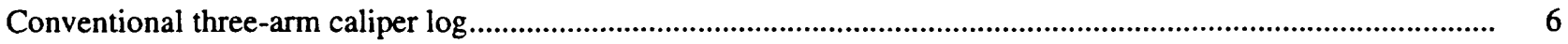

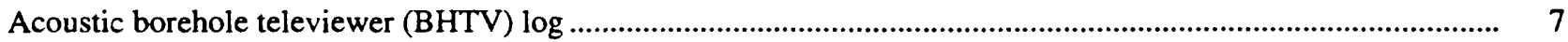

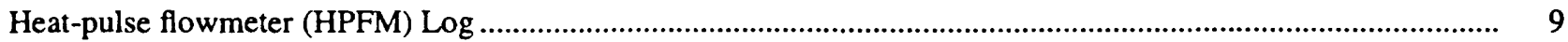

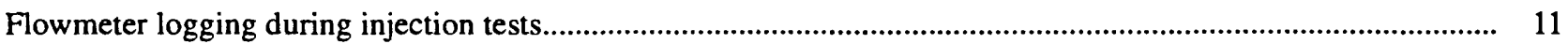

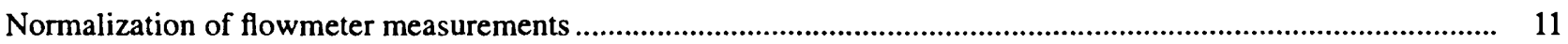

Identification and characterization of fractures and producing intervals in the Millville boreholes .............................. 14

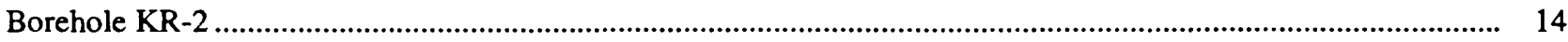

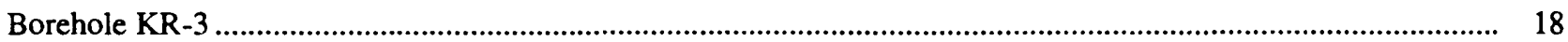

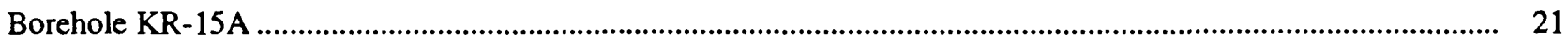

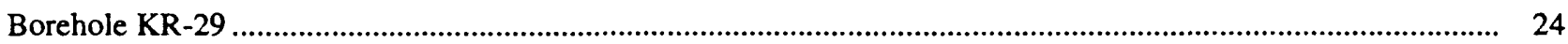

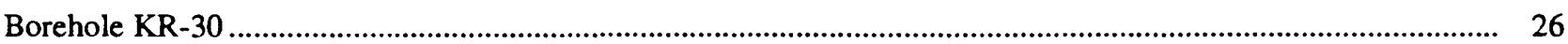

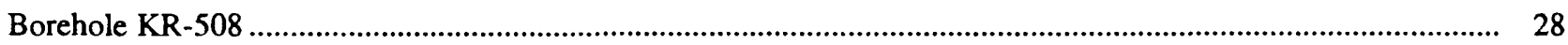

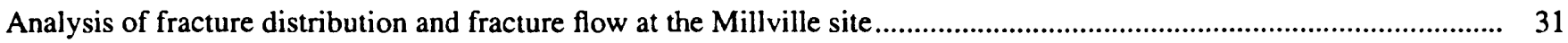

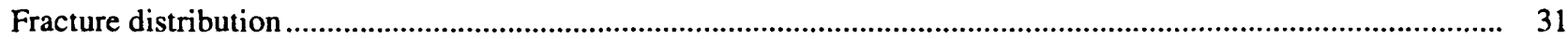

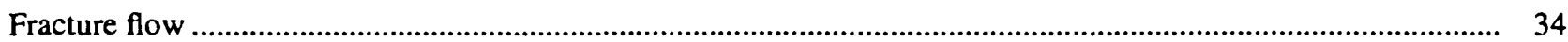

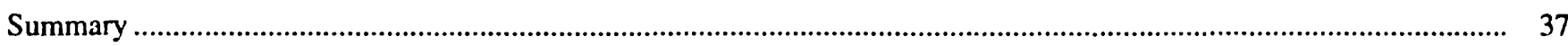

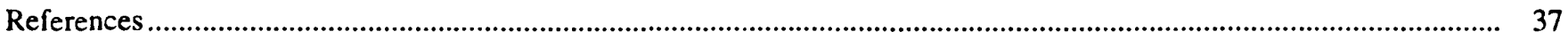

\section{FIGURES}

1. Map showing locations of the Millville, Massachusetts, study site, private water wells sampled, and concentrations of volatile organic compounds detected in the vicinity of the study site

2. Map showing location of boreholes KR-2, KR-3, KR-15A, KR-29, KR-30, and KR-508 at the Millville study site, and section showing depths where flow enters the borehole under ambient conditions and where injection tests indicate flow would enter the borehole during pumping

3. Schematic illustration of fracture plane intersecting a cylindrical borehole, indicating how the strike and dip of the fracture is interpreted from televiewer log images of the intersection between the fracture plane and the borehole wall

4. Graph showing calibration of thermal-pulse flowmeter measurements.

5. Graph showing water-level increase in casing during injection and downflow measured near the bottom of casing.

6. Single-point resistance, spontaneous potential, caliper, acoustic borehole televiewer, and flowmeter logs obtained under ambient hydraulic-head conditions in borehole KR-2

7. Explanation of acoustic borehole televiewer and flowmeter log data representation used in this report.

8. Natural gamma, temperature, single-point resistance, spontaneous potential, caliper, and acoustic borehole televiewer logs and flowmeter logs obtained under ambient hydraulic-head conditions and during injection in borehole KR-3.

9. Single-point resistance, spontaneous potential, caliper, borehole televiewer logs and flowmeter logs obtained under ambient hydraulic-head conditions and during injection in borehole KR-15A

10. Caliper, acoustic borehole televiewer, and flowmeter logs obtained under ambient hydraulic-head conditions in borehole KR-29. 
11. Natural gamma, single-point resistance, spontaneous potential, caliper, acoustic borehole televiewer logs and flowmeter log obtained during injection in borehole KR-30

12. Single-point resistance, spontaneous potential, caliper, and acoustic borehole televiewer logs and flowmeter log obtained during injection in borehole KR-508.

13. Equal area plots showing (A) poles to all fractures detected on televiewer logs for the Millville boreholes, and (B) poles to joints mapped in surface bedrock exposures at the Millville study site

14. Equal area plots showing (A) poles to fractures associated with televiewer size scores greater than 2, and (B) poles to fractures associated with inflow or outflow under ambient hydraulic-head conditions or during injection tests at the Millville study site

\section{TABLE}

1. Tetrachloroethene (PCE), trichloroethene (TCE), and 1, 1, 1-trichloroethane (TCA) concentrations in private water-supply wells exhibiting downflow under ambient hydraulic-head conditions 


\section{CONVERSION FACTORS}

Multiply

foot (ft)

inch (in.)

mile (mi)

gallon (gal)

gallon per minute (gal/min)
By

0.3048
25.4
1.609
3.785
0.06309

To obtaln

meter

millimeter

kilometer

liter

liter per second

The following terms and abbreviations also are used in this report:
ohm-meters (ohm-m)
megahertz $(\mathrm{MHz})$
microgram per liter $(\mu \mathrm{g} / \mathrm{L})$
milligram per liter $(\mathrm{mg} / \mathrm{L})$
milligram per kilogram $(\mathrm{mg} / \mathrm{kg})$
rotations per second (rps)
parts per billion (ppb)

Sea level: In this report "sea level" refers to the National Geodetic Vertical Datum of 1929 (NGVD of 1929)-a geodetic datum derived from a general adjustment of the first-order level nets of both the United States and Canada, formerly called Sea Level Datum of 1929. 


\title{
Identification, Characterization, and Analysis of Hydraulically Conductive Fractures in Granitic Basement Rocks, Millville, Massachusetts
}

\author{
By F.L. Paillet and Paul Ollila
}

\begin{abstract}
A suite of geophysical logs designed to identify and characterize fractures and water production in fractures was run in six bedrock boreholes at a ground-water contamination site near the towns of Millville and Uxbridge in south-central Massachusetts. The geophysical logs used in this study included conventional gamma, single-point resistance, borehole fluid resistivity, caliper, spontaneous potential, and temperature; and the borehole televiewer and heat-pulse flowmeter, which are not usually used to log bedrock water-supply wells. Downward flow under ambient hydraulic-head conditions was measured in three of the boreholes at the site, and the profile of fluid column resistivity inferred from the logs indicated downward flow in all six boreholes. Steady injection tests at about 1.0 gallon per minute were used to identify fractures capable of conducting flow under test conditions. Sixteen of 157 fractures identified on the televiewer logs and interpreted as permeable fractures in the data analysis were determined to conduct flow under ambient hydraulic-head conditions or during injection. Hydraulic-head monitoring in the bedrock boreholes indicated a consistent head difference between the upper and lower parts of the boreholes. This naturally occurring hydraulic-head condition may account, in part, for the transport of contaminants from the overlying soil into the bedrock aquifer. The downward flow may also account for the decrease in contaminant concentrations found in some boreholes after routine use of the boreholes as water-supply wells was discontinued.
\end{abstract}

\section{INTRODUCTION}

Predicting the transport of contaminants in fractured rock bodies is one of the most difficult problems in hydrogeology. Much of this difficulty is a consequence of the heterogeneity of fractured rocks. For example, the distribution of fracture permeability may vary in a random way in all directions, making it nearly impossible to specify the transmissivity values to be used in a transport model. Borehole geophysical methods (well logs) are one of the most useful means for determining fracture permeability in boreholes.

The geophysical study described in this report was undertaken as part of a U.S. Geological Survey program to develop well-logging techniques for the characterization of the hydraulic properties of fractured rocks. The work described in this report was supported in part by the State of Massachusetts Department of Environmental Protection (MADEP). The study site was used for testing of well-logging equipment and well-log analysis techniques used in fracture characterization and for studying how borehole geophysics might be used to understand how fractures contribute to the dispersal of hydrocarbon contamination of ground water in a fractured crystalline bedrock aquifer. The large number of bedrock boreholes available for sampling at this site and the pattern of contaminant-concentration data indicated by sample analyses represents an independent source of information on the nature of contaminant transport from the assumed point of introduction providing a useful check on the interpretations based on well-log data. 


\section{Purpose and Scope}

This report presents geophysical well-log data and interpretations used to identify and characterize fractures and to analyze fracture distribution and fracture flow at a site in south-central Massachusetts. The geophysical well-log data are presented in a format designed to be accessible to hydrogeologists interested in fracture hydrology and specification of properties for contaminant-transport models. These data include borehole wall images and caliper logs that indicate the distribution of fractures in five boreholes located along the axis of the distribution of contaminated wells. The data also include flowmeter profiles obtained under ambient hydraulic-head conditions and during injection tests. The flowmeter log data may be used to infer the location of fractures capable of producing water during pumping. The data provide useful information about the fractures encountered in six boreholes at the study site and about the subset of those fractures associated with hydraulic transport during pumping. The distribution and orientation of fractures in the boreholes are compared to the distribution and orientation of fractures identified on outcrops, and the general distribution of fractures is used to infer the large-scale distribution of bedrock permeability. This report is written to make that data available to U.S. Geological Survey and State of Massachusetts scientists engaged in the long-term study of the Millville, Massachusetts, fractured rock aquifer.

\section{Description of the Millville Site}

The study site is in south-central Massachusetts approximately $5 \mathrm{mi}$ north of the Rhode Island border in the towns of Millville and Uxbridge (fig. 1). Although the study site extends into both Millville and Uxbridge, most of the boreholes logged as part of the study described in this report are located in Millville, and here after the study site is referred to as the Millville site. The area is predominantly rural-residential, and most private residences in the area were constructed after 1989. The six boreholes logged at the study site are located along Kempton Road on the west side of a broad hilltop at an elevation of approximately $460 \mathrm{ft}$ above sea level (fig. 2). The ground surface slopes gently to the west and southwest near the location where one or more suspected surface spills of hydrocarbons may have served as the source for the visible contamination (fig. 1). Steeper slopes at the edges of the hilltop drop 100 to $200 \mathrm{ft}$, and drainage generally is towards the Blackstone River located west, south, and southeast of the site.

The area in the vicinity of the contaminated soils at the suspected source of the contamination is underlain by a thin, fairly uniform, compact till (HMM Associates, Inc., 1993). Borings at the edge of Kempton Road near the area of contaminated soil commonly encountered light-brown, fine to coarse sand with some silt and gravel. South of the road near the contaminated soils, 0.5 to $1 \mathrm{ft}$ of topsoil is typically underlain by $1-2 \mathrm{ft}$ of light-brown, very fine to fine sand with a little silt and locally a trace of subangular gravel and 3 to $10 \mathrm{ft}$ of light-gray, fine to coarse sand with a little subangular gravel and silt. Refusal depths for borings advanced in and around the visibly contaminated soils ranged between 5.5 and $7.5 \mathrm{ft}$. One hundred feet west of the visibly contaminated soils, refusal depths increase to $17 \mathrm{ft}$. Bedrock is exposed approximately $150 \mathrm{ft}$ east of the visibly contaminated soils.

Based on the mapping by McKniff (1964), all contaminated bedrock wells are located within intermixed light-gray, medium- to coarse-grained quartz diorite gneiss and dark-gray to black amphibolite. Quartz diorite gneiss is the most abundant rock type in the vicinity of the site, based on observations of rock excavated during installation of public water-supply lines, shallow bedrock cores, and nearby outcrops. These granitic rocks are late Precambrian in age and occupy the core of a regional antiform (Goldsmith, 1991). Metamorphosed sedimentary rocks south and west of the site consist of quartzites and quartz-biotite schists. The nearest contacts with metamorphosed sedimentary rocks are approximately $3,000 \mathrm{ft}$ south of the study site. These rocks were metamorphosed under amphibolite facies conditions (McKniff, 1964; Goldsmith, 1991). 


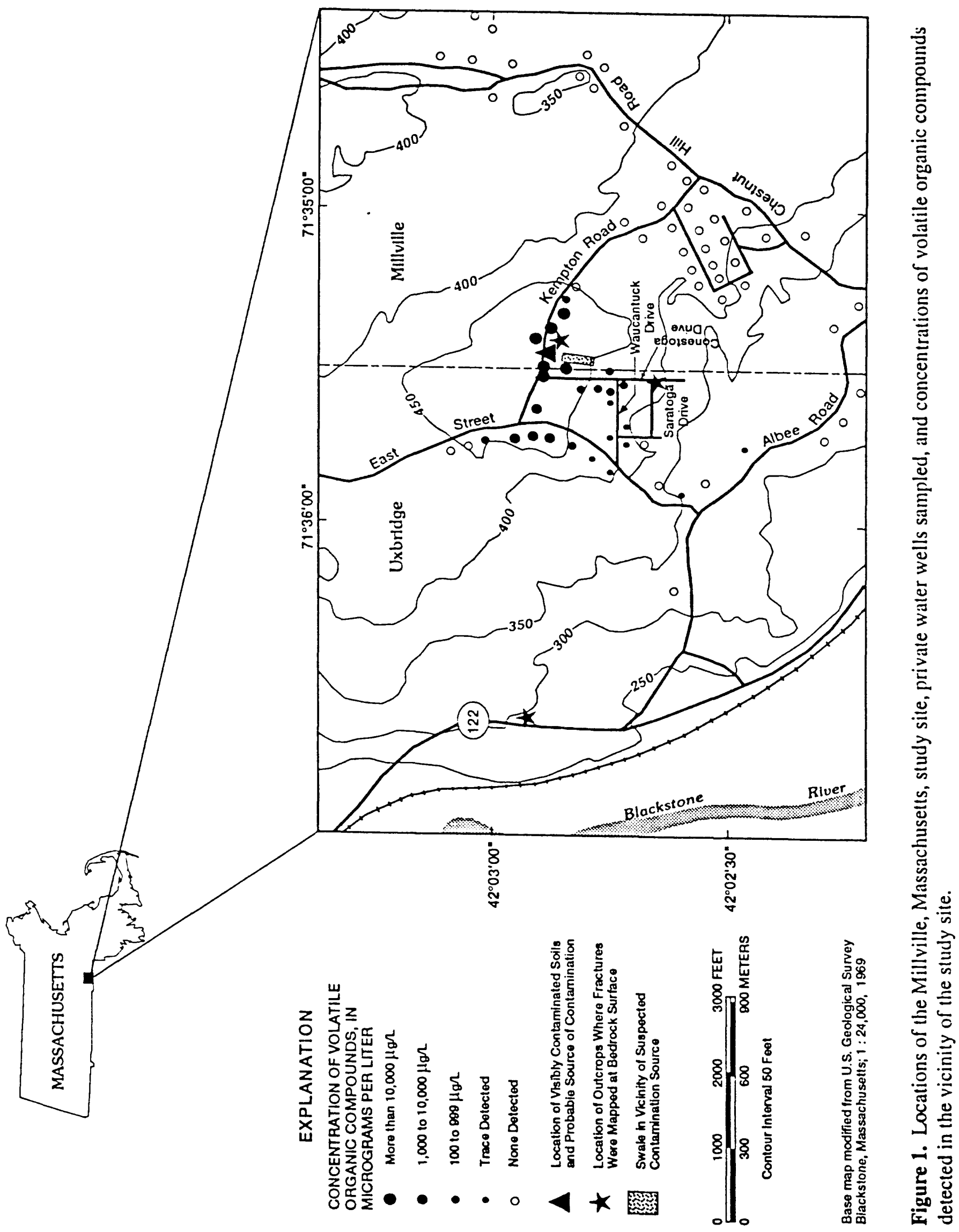




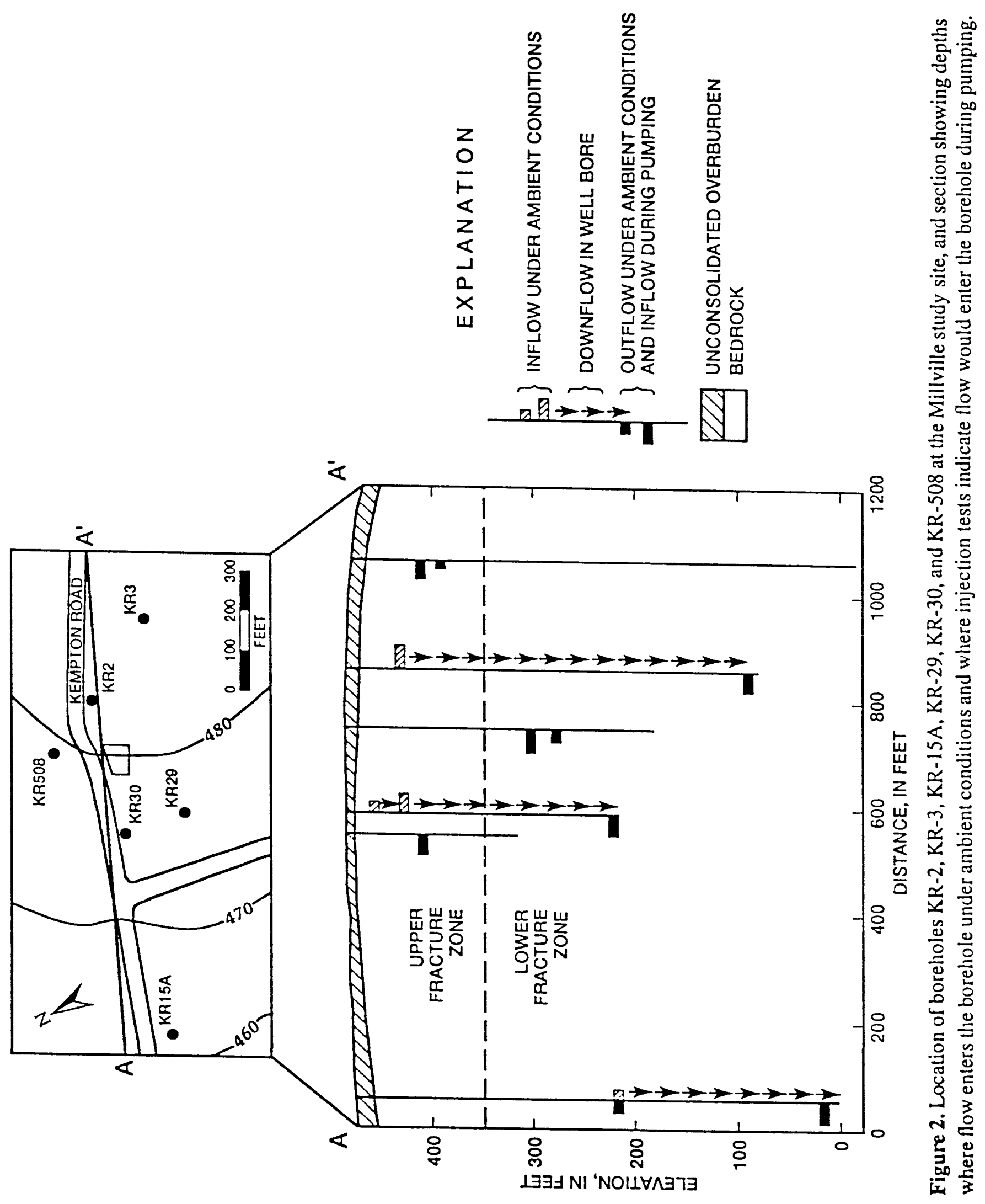


In general, foliation in the granitic rocks parallels foliation in the surrounding metamorphosed sedimentary rocks. Complex map patterns between granitic rocks and surrounding metamorphosed sedimentary rocks may result from fold interference caused by refolding of nappe structures or from low-angle ductile deformation (Goldsmith, 1991). Locally, both foliation and contacts with metamorphosed sedimentary rocks define a broad, northeast-plunging synform. The state geologic map (Zen and others, 1983) shows a northwest-trending fault located approximately $2,000 \mathrm{ft}$ north of the site.

Strike and dip of fractures and joints were measured on three outcrops in the vicinity of the study site (fig. 1). One outcrop, located $150 \mathrm{ft}$ east of the contaminated soils, consists of quartz-diorite gneiss and is approximately $20 \mathrm{ft}$ long by $5 \mathrm{ft}$ wide. The small number of measured joints at this outcrop reflects the limited exposure. Another outcrop is located $1,600 \mathrm{ft}$ south-southwest of the contaminated soils at the intersection of Conestoga and Saratoga Drives. Most of the outcrop consists of quartz diorite gneiss. However, discontinuous amphibolite layers and lenses and a quartzite xenolith are present in the southern end of the outcrop. McKniff's (1964) geologic map shows this location to be near the contact between a map-scale amphibolite body and surrounding mixed quartz diorite gneiss and amphibolite. Joint data were recorded along north-south $(58 \mathrm{ft})$ and east-west $(45 \mathrm{ft})$ traverses on this outcrop.

A third outcrop is a 50-ft-long roadcut in quartz-diorite gneiss along Route 122 approximately $5,000 \mathrm{ft}$ west of the study site. Although this exposure is located at some distance from the study site, this is the nearest location where a large, continuous roadcut is available for study. Joint data were recorded along two traverses oriented parallel (N-S, $48 \mathrm{ft}$ in length) and perpendicular ( $\mathrm{E}-\mathrm{W}, 13 \mathrm{ft}$ in length) to the road. Most measured joint lengths were greater than the length of the outcrop exposure.

Contamination at the Millville site was first detected in June 1991 when a sample from a newly installed, 175-ft-deep, private water-supply well was analyzed for volatile organic compounds (VOCs). High concentrations of tetrachloroethene (PCE), trichloroethene (TCE) and 1,1,1-trichloroethane (TCA) and lower concentrations of other hydrocarbons were detected. Following this discovery, the MADEP sampled five additional private water-supply wells and found that all five wells were contaminated. Three wells had concentrations in excess of $50,000 \mu \mathrm{g} / \mathrm{L}$ of total VOCs. In addition, the MADEP and the United States Environmental Protection Agency (USEPA) found high levels of chlorinated solvents in soils in a 20 - by 40 -ft area characterized by dead vegetation in the visibly contaminated area (fig. 2 ) on the south side of Kempton Road near the contaminated wells.

Subsequent sampling by local boards of health, the USEPA, and the MADEP identified 25 contaminated wells within a radius of approximately $2,000 \mathrm{ft}$ from the visibly contaminated soils (fig. 1). The most highly contaminated wells are located immediately adjacent to the contaminated soils. However, concentrations as high as $2,000 \mu \mathrm{g} / \mathrm{L}$ PCE were detected in wells approximately $1,000 \mathrm{ft}$ to the west-northwest. The USEPA provided temporary alternative water supplies during December 1991, and municipal water lines were brought into the area during the summer of 1992.

During 1991-92, the water table ranged from approximately 1 to $9 \mathrm{ft}$ below the ground surface in the contaminated soil area at the Millville site. The highest levels were recorded in November 1991, and the lowest levels were recorded during the late summer of 1992. Based on water-level data from the winter and spring of 1991-92, ground-water flow in the surficial aquifer is to the west-southwest in the vicinity of the contaminated soils. A north-south- trending low area (the swale) located $150 \mathrm{ft}$ west of the area of visibly contaminated soils and just east of wells KR-30 and KR-29 (fig. 2) contains an intermittent stream during high ground-water periods.

Bedrock water-supply wells at the Millville site are 6 inches in diameter and range in depth from 140 to $840 \mathrm{ft}$ in depth. Well yields, based on driller's logs, typically are less than $6 \mathrm{gal} / \mathrm{min}$. However, two wells had reported yields of 80 and $100 \mathrm{gal} / \mathrm{min}$, and one well had a reported yield of $30 \mathrm{gal} / \mathrm{min}$. Strong downward hydraulic gradients exist in the bedrock aquifer and will be discussed later in this report. 


\section{DESCRIPTION OF EQUIPMENT AND HYDRAULIC TEST PROCEDURES}

A number of conventional geophysical well logs and other experimental geophysical logging techniques can be used to identify fractures intersecting boreholes in crystalline basement rock (Keys, 1979, 1991; Paillet 1991). Some of the Millville boreholes were logged with a suite of conventional logs including natural gamma, single-point resistance, borehole fluid resistivity, caliper, spontaneous potential, and temperature logs. All of these logs are described in detail in a number of readily available references (for example, Keys, 1991) and will not be described here. The natural gamma and temperature logs did not appear to contribute much to this study and were not run in most of the boreholes. The spontaneous potential logs did not appear to contain any information not contained in the single-point resistance log.

Of the suite of conventional geophysical logs run for this study, only the single-point resistance and caliper logs appeared useful in fracture identification and characterization in fractured crystalline rocks. Only these two logs are discussed in detail in this report. In addition to these two conventional geophysical logs, two other geophysical logs not usually available for ground-water studies were used to characterize fractures at the Millville site: the acoustic borehole televiewer (BHTV) and the heat-pulse flowmeter (HPFM). These two geophysical logs are described in more detail below.

\section{Single-Point Resistance Log}

The single-point resistance log is one of many different kinds of electric logs that can be run in a borehole. Of the relatively unsophisticated electric logs available for this study, the single-point resistance $\log$ is considered the most suitable for fracture characterization (Keys, 1979; Paillet, 1991). The singlepoint resistance log was originally designed to measure the total resistance between a measurement electrode in the borehole and a return electrode located on the surface. Because both measurement and current electrode are located at the same point on the logging tool, the measurement cannot be related to a specific sample volume. However, the single-point resistance log is not subject to thin bed effects associated with interpretation of long and short normal resistivity logs and is preferred for fracture studies where fractures are analogous to thin conductive beds in a nonconductive formation (Paillet, 1991).

The version of the single-point log used in this study is known as a differential single-point log (Keys, 1991). This log was developed because the return current path in conventional single-point systems often involves the logging cable or casing rather than the surface electrode. The differential single-point logging probe controls the position of the return electrode by including a return electrode located on the surface of the logging tool about 2 inches from the source electrode. The differential single-point probe is effective in fracture detection and characterization because the log responds to both changes in water quality in the borehole and to very thin variations in the resistance of the formation around the borehole. Changes in salinity of the fluid column appear as shifts in the average resistance recorded by the log. Fractures appear as thin, electrically conductive "beds" in the form of spike-like anomalies where the log is deflected towards low resistivities immediately adjacent to the fracture-borehole intersection.

\section{Conventional Three-Arm Caliper Log}

The conventional caliper log measures average borehole diameter by recording the average of the extension of three spring-loaded arms. The arms are about 0.25 inch in diameter and 6.0 inches in length. The borehole probe is designed so that the resistance of probe circuitry varies almost linearly with the average extension of the caliper arms. Caliper logs indicate the abrupt, local borehole enlargements where fractures intersect the borehole, so the caliper log can be a useful fracture indicator (Keys, 1979, 1991). However, the natural aperture of individual fractures is almost always smaller than the diameter of the caliper arms, so the tips of the caliper arms cannot fit into such openings. Therefore, the borehole enlargements sensed by caliper logs usually represent enlargements of the borehole-fracture intersection produced 
by spalling during drilling or by erosion of soft alteration products and fracture infilling clays. For this reason, anomalies on caliper logs are used as indirect indicators of fracturing (Keys, 1979).

\section{Acoustic Borehole Televiewer (BHTV) Log}

The BHTV log produces a photographic image of the borehole wall that indicates the intensity of acoustic reflection from a source scanning the borehole wall at 3 rps (Zemanek and others, 1970; Paillet and others, 1990). The source transducer uses a $1.25 \mathrm{MHz}$ signal and has a beam width of about $0.3 \mathrm{inch}$. At those depths where fractures intersect the borehole wall, the intersection scatters acoustic energy, which produces a linear feature on the photographic output from the BHTV (fig. 3). The orientation of these features can be used to infer strike and dip of fractures with respect to the borehole axis. The azimuthal orientation of the televiewer image is determined by the local direction of magnetic north. Laboratory calibrations and other equipment checks indicate that the BHTV horizontal sweeps are triggered within a few degrees of the component of the Earth's magnetic field in the plane transverse to the borehole axis.

Unless boreholes are deviated more than 40 degrees from the vertical at sites in southern New England, all azimuths given on BHTV logs have an estimated error of less than about 5 degrees.

The azimuth triggering mechanism of the BHTV logging system determines orientation of BHTV image logs but is not the only factor that determines the error in estimating the strike and dip of fractures identified on logs. Errors in the interpretation of fracture strike and dip can result from departures of the fracture image from the expected shape indicated in figure 3 . Whenever fractures have the expected shape as predicted for the intersection of a planar feature with a cylindrical borehole, fracture strike and dip can be estimated to within an error of \pm 10 degrees. The vertical scale of image logs also determines the ability to discriminate between shallow-dipping and horizontal fractures. When a vertical scale of 2 feet per inch is used, experience indicates that a fracture needs to be dipping at more than 15 degrees from horizontal before the dip can be identified on the BHTV log images.

BHTV logs provide a qualitative indication of fracture size because fractures with larger apertures appear as wider, darker features on the BHTV display. The width of the linear feature associated with a fracture can be inferred from the scale of the photographic output of the logging system, but the width of these lines represents fracture aperture at the borehole wall convolved with the 0.3 -inch-wide source beam. The fracture width at the borehole wall has also been enlarged during drilling, so an aperture measured there would not be representative of the fracture aperture in the undamaged formation. Specific examples of the interpretation of fracture aperture using BHTV logs are given by Keys (1979), Paillet and others (1985), and Paillet (1991). The general term "size" is used here as a way of describing all of the attributes on the BHTV log that are associated with local hydraulic aperture. These attributes include the thickness of the linear feature on the log interpreted as a fracture, the degree of interconnectedness of fractures within a fracture zone, and the amount of alteration and drilling damage associated with the fracture image. These attributes are difficult to quantify. However, it is important to include some qualitative estimate of the size and possible permeability of fractures in the interpretation. The qualitative information on the BHTV log is translated into a quantitative scale by assigning a score to each fracture identified on the BHTV log. The scores range from 1 for a fracture that has only a small probability of transmitting flow to 5 for a very large opening with an apparent aperture of more than $0.5 \mathrm{ft}$ in the immediate vicinity of the borehole. This analysis is based on an extensive comparative analysis of BHTV logs, core studies, and packer tests where the relative sizes of BHTV fracture images are found to indicate the relative apertures of fractures within a small distance from the borehole wall (less than $0.1 \mathrm{ft}$ ) after allowance is made for the effects of drilling and erosion of infilling minerals (Paillet and others, 1985; Paillet and others, 1987b). Detailed explanation and documentation of the fracture scoring method is given by Paillet and Kapucu (1990). 

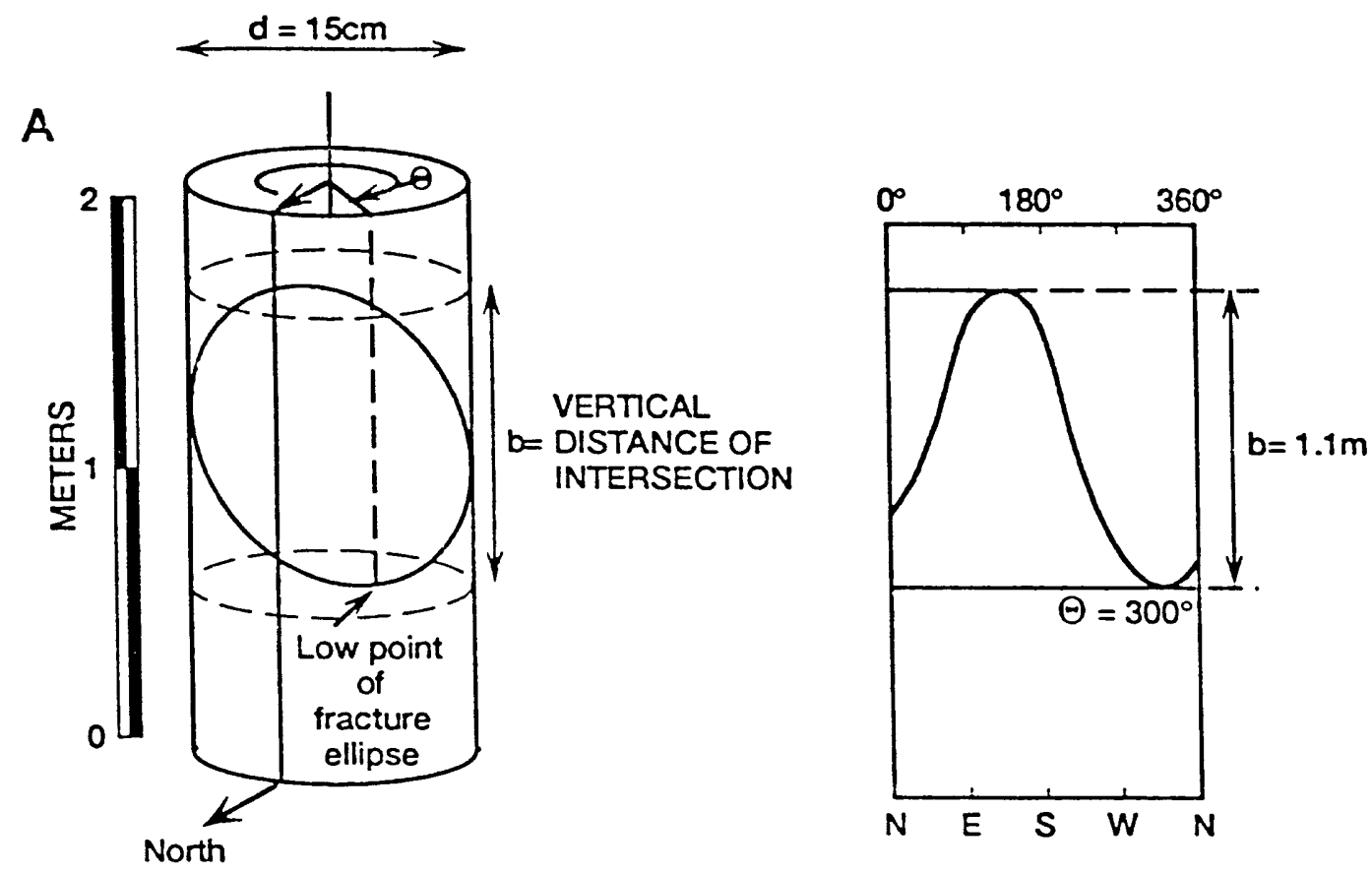

B

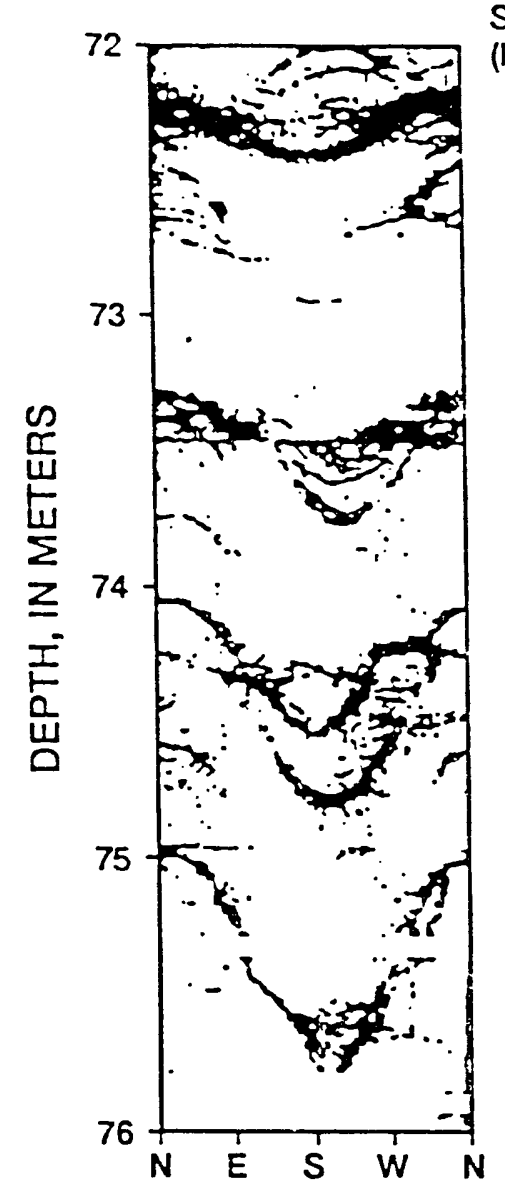

$D i p=\tan ^{-1}\left(\frac{b}{d}\right)=\tan ^{-1}\left(\frac{110}{15}\right)=82^{\circ}$

Strike $=\theta-90^{\circ}=210^{\circ}$

(Right Hand Rule)

Figure 3. Schematic illustration of fracture plane intersecting a cylindrical borehole, indicating how the strike and dip of the fracture is interpreted from televiewer log images of the intersection between the fracture plane and the borehole wall. 


\section{Heat-Pulse Flowmeter (HPFM) Log}

The HPFM was developed to provide a borehole flowmeter with greater sensitivity than conventional impeller flowmeters, which require axial flow velocities larger than several feet per minute to turn the impeller blades (Keys, 1991). The HPFM measures axial flows along the borehole at discrete depths by detecting the time required for a small volume of thermally tagged water to travel from a heat grid to a thermistor in the measurement section of the tool (Hess, 1986). The sensitivity of the HPFM is increased by the use of a downhole packer system that uses an inflatable bladder to block the annulus around the tool, which forces all flow through the measurement section. With the packer inflated, the inverse of heat-pulse travel time is calibrated in terms of borehole discharge in gallons per minute (fig. 4). Experiments at the U.S. Geological Survey flowmeter calibration facility demonstrate that the HPFM can detect flows as small as $0.02 \mathrm{gal} / \mathrm{min}$ (Hess and Paillet, 1990). 


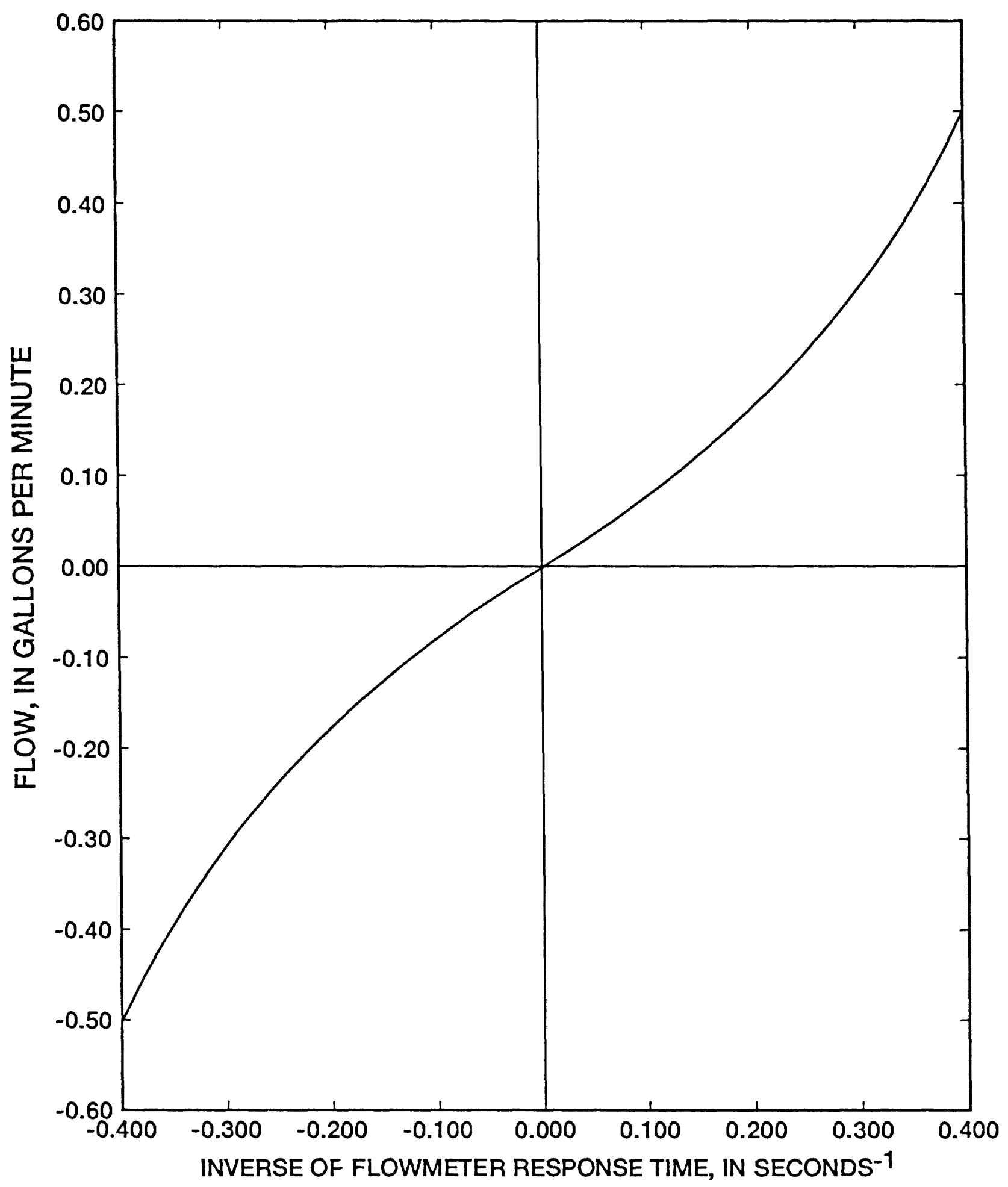

Figure 4. Calibration of heat-pulse flowmeter measurements; the inverse of heat-pulse travel time either up or down the borehole is related to borehole discharge in gallons per minute when the downhole packer is inflated. 


\section{Flowmeter Logging During Injection Tests}

Based on experience at several fractured-rock study sites (Paillet, 1991), the U.S. Geological Survey has developed a standardized procedure for using HPFM measurements during pumping or injection to identify transmissive fractures (Paillet and others, 1987a). Before injection is started, the HPFM is lowered into the borehole and measurements are made at various depths to determine whether there is flow along the borehole driven by ambient hydraulic-head differences between fractures. If such ambient flow exists, HPFM measurements are made to identify the depths where flow enters and exits the borehole.

For the injection phase of the test, water is added to a borehole at a nearly steady rate of about $1.0 \mathrm{gal} / \mathrm{min}$. HPFM measurements are started 15 minutes to an hour after the beginning of injection. HPFM measurements are made during the injection at discrete depths between where fractures intersect the borehole. Water-level measurements are made at regular intervals during injection, if possible.

\section{Normalization of Flowmeter Measurements}

HPFM measurements made during the injection test need to be adjusted to correct for variation in the proportion of the constant injection rate that contributes to storage in the well bore (Paillet and Kapucu, 1989). The proportion of injected water that goes into well-bore storage generally decreases with time as flow into the formation increases. Therefore, the magnitude of flow in the well bore below the casing changes during the test, and HPFM data need to be normalized to correspond to recharge conditions at a given time. It is assumed that the increase in water level in casing is proportional to the total rate of flow to the formation, and estimates of water-level increase can be used to normalize the data. HPFM measurement normalization is accomplished by fitting the measured water-level buildup over time to a smooth exponential curve. The fraction of injected water accepted by the formation is assumed to be proportional to the increase in water level above static conditions at any given time during the injection test.

Although the flow-normalization method effectively removed most of the effects of the transient evolution of the flow field at other fractured-rock study sites (Paillet and Kapucu, 1989), the normalization did not appear to be very effective for the Millville data. Flow transients were not a problem when HPFM measurements were made under ambient conditions because the naturally occurring flow did not appear to vary with time. However, the measured downflow did change during the measurement period during injection tests. In each injection test, the measured downflow at a particular depth point near the bottom of casing was found to increase as water level in casing increased during the test. However, the measured flows were not very effectively normalized by adjustment of measured values using the formula:

$$
Q_{N}(z)=Q(z, t) \frac{S_{o}}{S(t)}
$$

where

$Q_{N}(z)$ is the normalized flow in gallons per minute at depth $z$ in feet;

$Q(z, t)$ is the flow in gallons per minute measured at depth $z$ at time $t$ in minutes after start of injection;

$S(t)$ is the water-level increase in feet in casing at time $t$ after start of injection; and

$S_{o}$ is the maximum water-level increase in feet during injection. 
For example, the normalization using equation (1) increases the flow by only about two-thirds of the amount needed for effective normalization of flows measured at a depth of $30 \mathrm{ft}$ in borehole KR-3 (fig. 5A). The results are even less effective for borehole KR-30 (fig. 5B), where the normalization appears to overcompensate for the effects of water-level buildup in casing. Both of these examples indicate that flow in fractured aquifers cannot always be treated as quasi-steady flow in a single confined aquifer, where outflow during injection is known to be nearly proportional to driving hydraulic head. The effects of fractures above the ambient water level in the aquifer being saturated during the injection almost certainly influenced the measured downflow. Water levels in some of the boreholes were occasionally changing in a way that did not seem related to the injection tests, and these changes are assumed to be caused by pumping from the aquifer by nearby water wells. These extraneous drawdowns may also have affected the ability to normalize the HPFM data using equation (1). The departures from effective normalization indicated in figure 5 are assumed to be a consequence of the complexity of flow in the fractured rocks adjacent to boreholes KR-3 and KR-30, superimposed on the effects of the filling of storage above the water table in the shallow fractures, possibly coupled with the extraneous drawdowns attributed to pumping from the aquifer by adjacent water users.

The relative ineffectiveness of normalization of the HPFM measurements during injection induces an amount of uncertainty in the interpretation of the flow data. Some of this uncertainty can be reduced by considering the time when measurements are made in identifying depths where water is exiting the borehole during injection. A difference in measured flow at two depths is significant when measurements are made at closely spaced times but may not be significant if measurements are made at widely different times. The effects of an evolving flow field were taken into account qualitatively in the interpretation of HPFM measurements made during injection tests conducted as part of this study. 

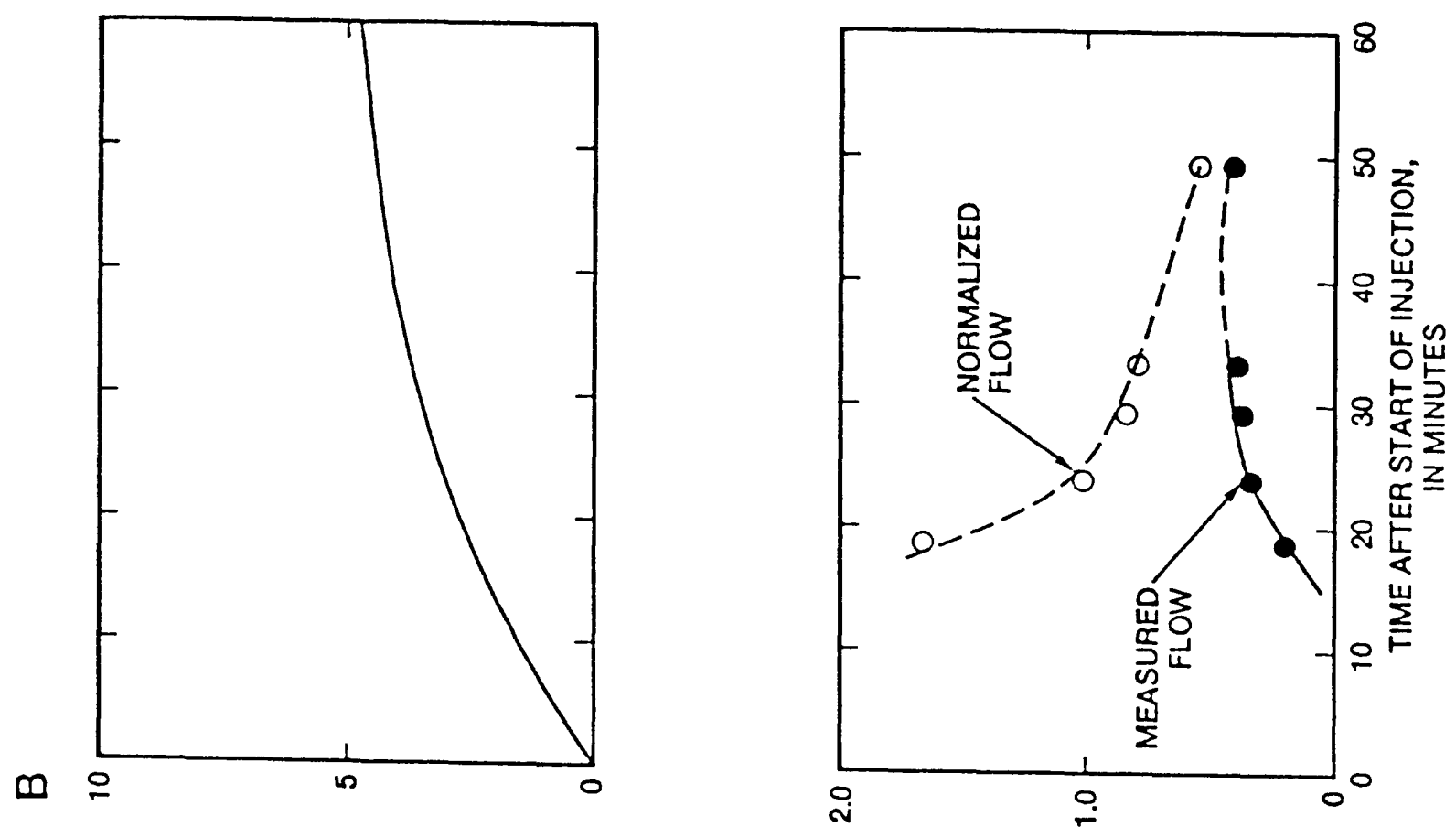

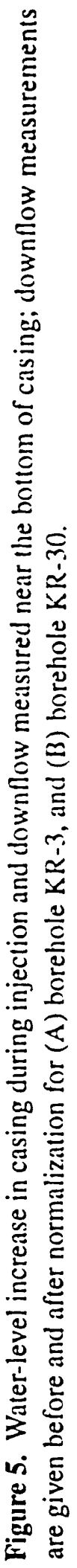
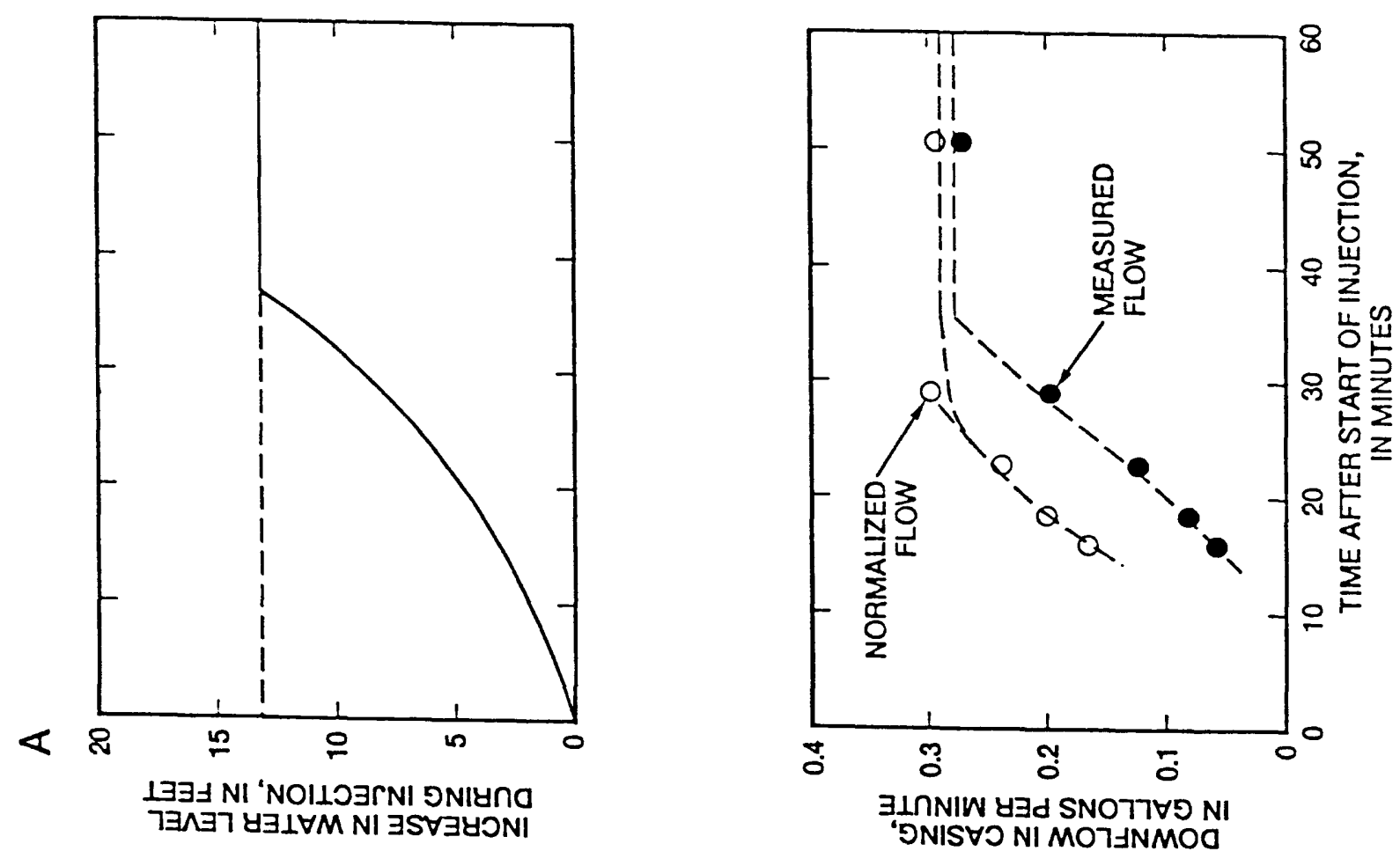


\section{IDENTIFICATION AND CHARACTERIZATION OF FRACTURES AND PRODUCING INTERVALS IN THE MILLVILLE BOREHOLES}

\section{Borehole KR-2}

The single-point resistance, caliper, and BHTV logs for borehole KR-2 indicate a number of fractures or fracture zones at depths above $80 \mathrm{ft}$ and very few or no fractures below that depth (fig. 7). However, BHTV logs were not obtained in the depth interval from $200 \mathrm{ft}$ to the bottom of the borehole ( $400 \mathrm{ft}$ ). Because photograpic images obtained by the BHTV logging system cannot be reduced to a scale comparable to that of the other logs, BHTV log data are indicated symbolically using the representation explained in figure 7. The representation used to indicate flowmeter log interpretation is also explained in figure 7. The resistance log contains anomalously low values above $70 \mathrm{ft}$ in depth; these values correspond to the fractures and fracture zones and probably also indicate weathering in the shallow bedrock.

Flowmeter measurements in borehole KR-2 made under ambient conditions indicated a strong downflow (between 0.3 and $0.5 \mathrm{gal} / \mathrm{min}$ ) over almost the entire length of the borehole (fig. 6). Some of the flow entered at the bottom of casing at about $30 \mathrm{ft}$ in depth, but most inflow occurred at a single large fracture indicated on the televiewer $\log$ at about $48 \mathrm{ft}$ in depth. The outflow occurred at one or more fractures below $370 \mathrm{ft}$ in depth. These fractures were considered below the depths of interest for the contaminant-transport study and were not logged with the BHTV. An injection test was not conducted for this borehole because ambient downflow was already approaching the upper limit of the HPFM resolution, and producing fractures seemed adequately characterized by HPFM measurements made under ambient conditions. 


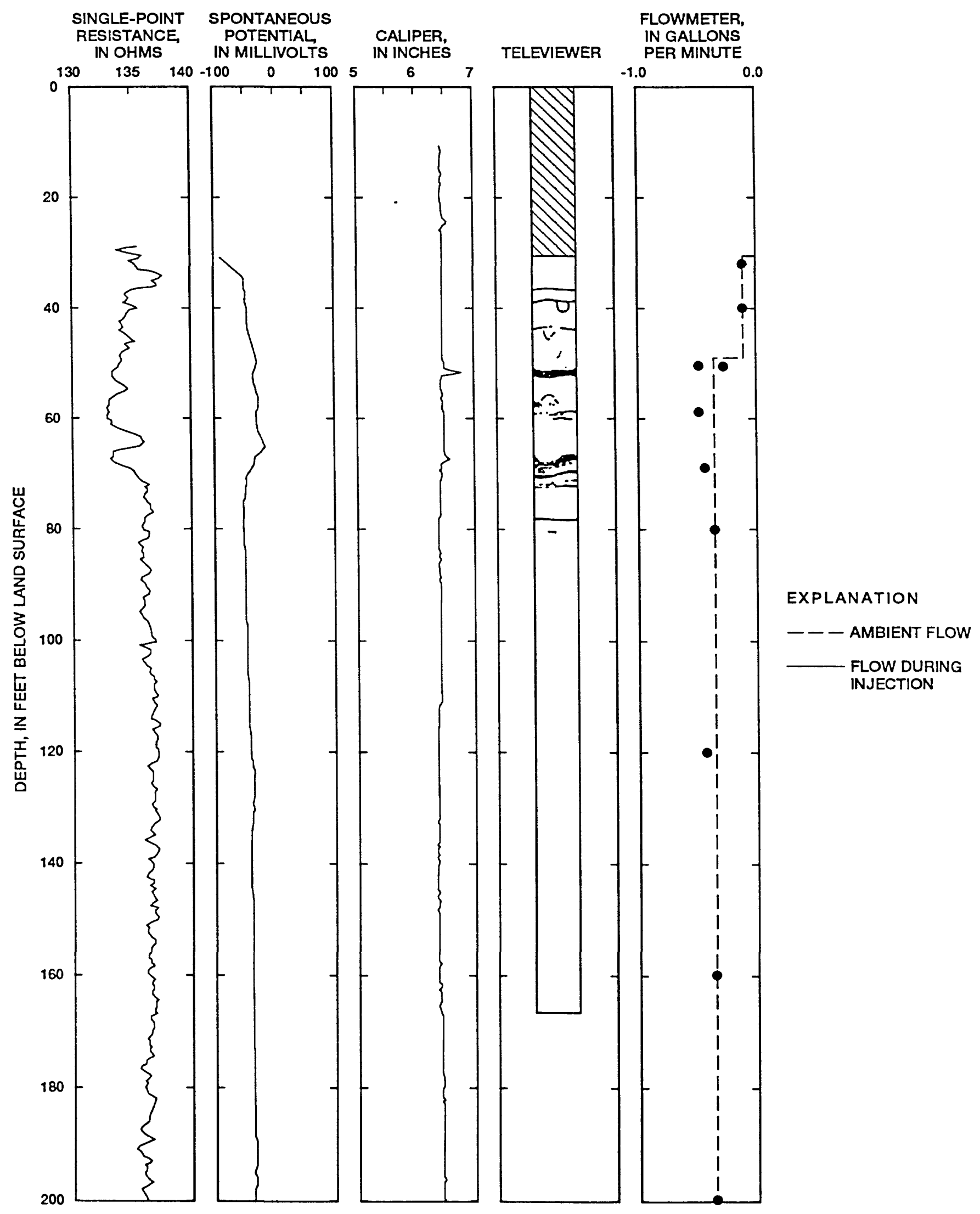

Figure 6. Single-point resistance, spontaneous potential, caliper, acoustic borehole televiewer, and flowmeter logs obtained under ambient hydraulic-head conditions in borehole KR-2. 


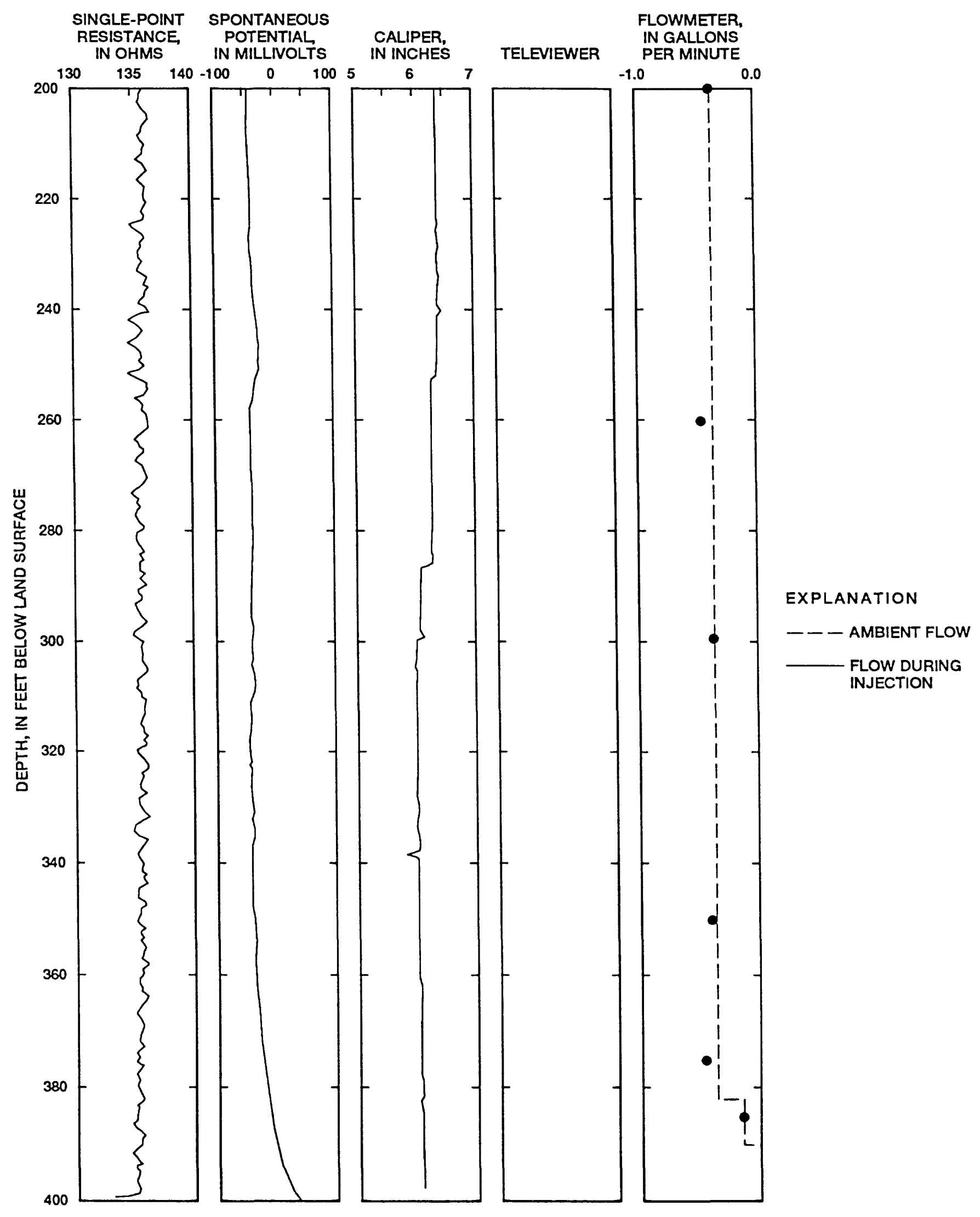

Figure 6. Continued. 


\section{EXPLANATION OF TELEVIEWER LOG DATA DISPLAY}

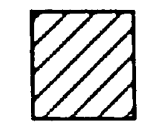

AIR FILLED BOREHOLE ABOVE WATER LEVEL

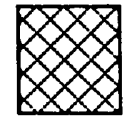

STEEL CASING FILLED WITH WATER

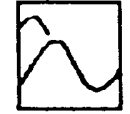

ISOLATED FRACTURES

INTERSECTING OPEN BOREHOLE

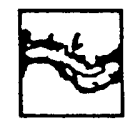

MAJOR FRACTURE ZONE

INTERSECTING OPEN BOREHLOE

\section{EXPLANATION OF HEAT PULSE FLOWMETER DATA DISPLAY}

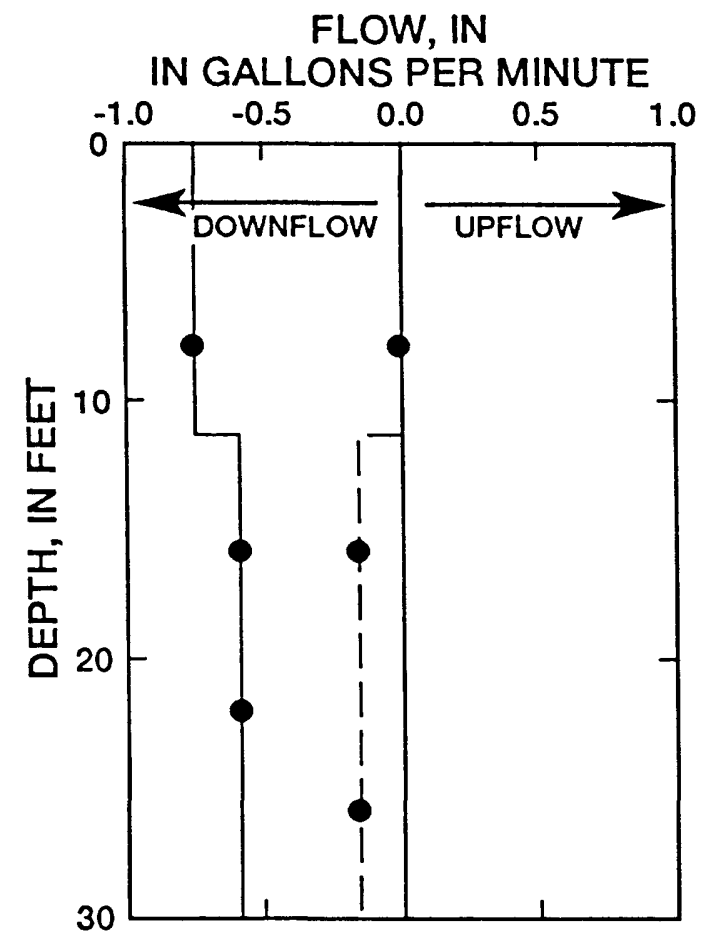

Figure 7. Explanation of acoustic borehole televiewer and flowmeter log data representation used in this report. 


\section{Borehole KR-3}

The caliper and BHTV logs for borehole KR-3 indicate a few fractures and fracture zones above 200 $\mathrm{ft}$ in depth in borehole KR-3 and very few or no fractures below that depth (fig. 8). Only fractures near 196,144 , and $40 \mathrm{ft}$ in depth appear associated with significant borehole enlargements on the caliper log. The single-point resistance log shows a gradual decrease in resistance over the interval from 180 to $240 \mathrm{ft}$ in depth that may indicate a change in water quality in the borehole. Although such stratification could be associated with flow under ambient conditions in the borehole, the temperature log does not contain any significant anomalies that would be associated with such flow except for a gradual increase in geothermal gradient below about $140 \mathrm{ft}$ in depth, which does not appear to indicate inflow or outflow at any specific depth.

Naturally occurring flow under ambient hydraulic-head conditions was not detected with the HPFM in borehole KR-3 (fig. 8). Based on the known resolution of the HPFM, any flow would have been less than $0.01 \mathrm{gal} / \mathrm{min}$. HPFM measurements obtained during injection at about $0.5 \mathrm{gal} / \mathrm{min}$ indicated that a significant part of the flow was going into storage in casing. Of about $0.3 \mathrm{gal} / \mathrm{min}$ downflow obtained during the last minutes of the injection experiment, about $0.1 \mathrm{gal} / \mathrm{min}$ exited at a fracture zone between 60 and 70 $\mathrm{ft}$ in depth, and the remaining $0.2 \mathrm{gal} / \mathrm{min}$ exited at a single, isolated fracture near $135 \mathrm{ft}$ in depth. The change in water quality below $180 \mathrm{ft}$ in depth shown on the single-point resistance log may indicate a very slow downward flow under ambient conditions that is below the minimum flow detectable with the HPFM and too small to induce a recognizable anomaly on the temperature log. 

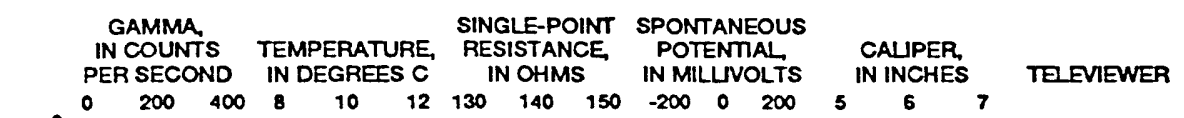

FLOWMETER PER SECOND IN DEGREES C IN OHMS IN MILLUVOLTS IN INCHES TELVIEWER

$$
{ }^{20}
$$

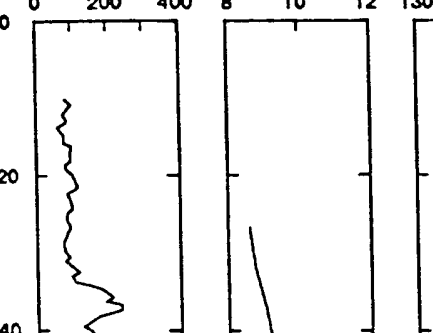

40

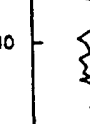

so

so

80

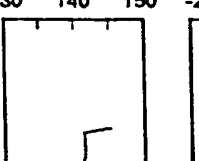

T1
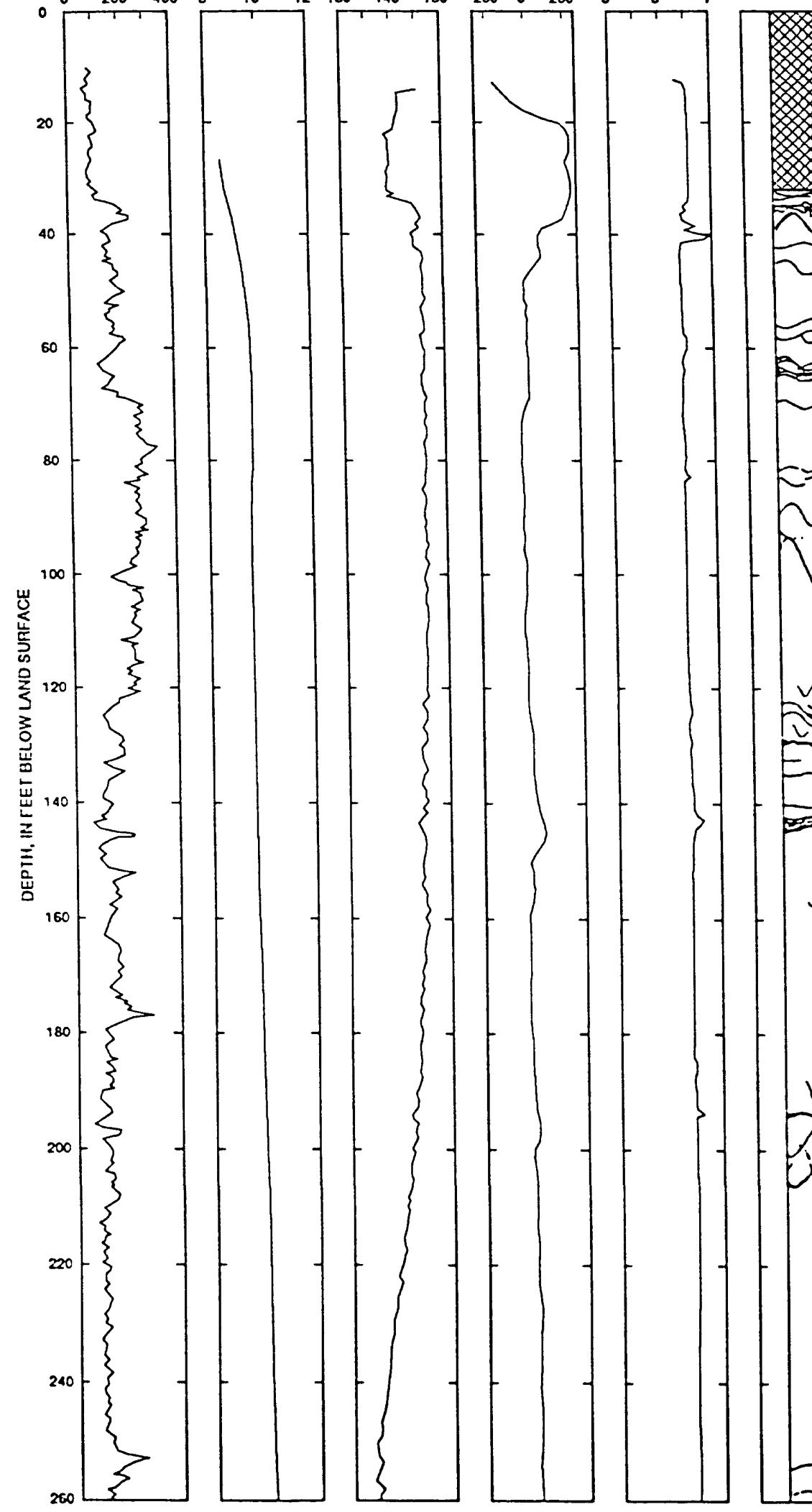

)

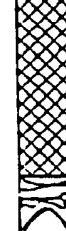

3

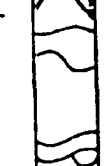

$+$ 0.0

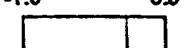




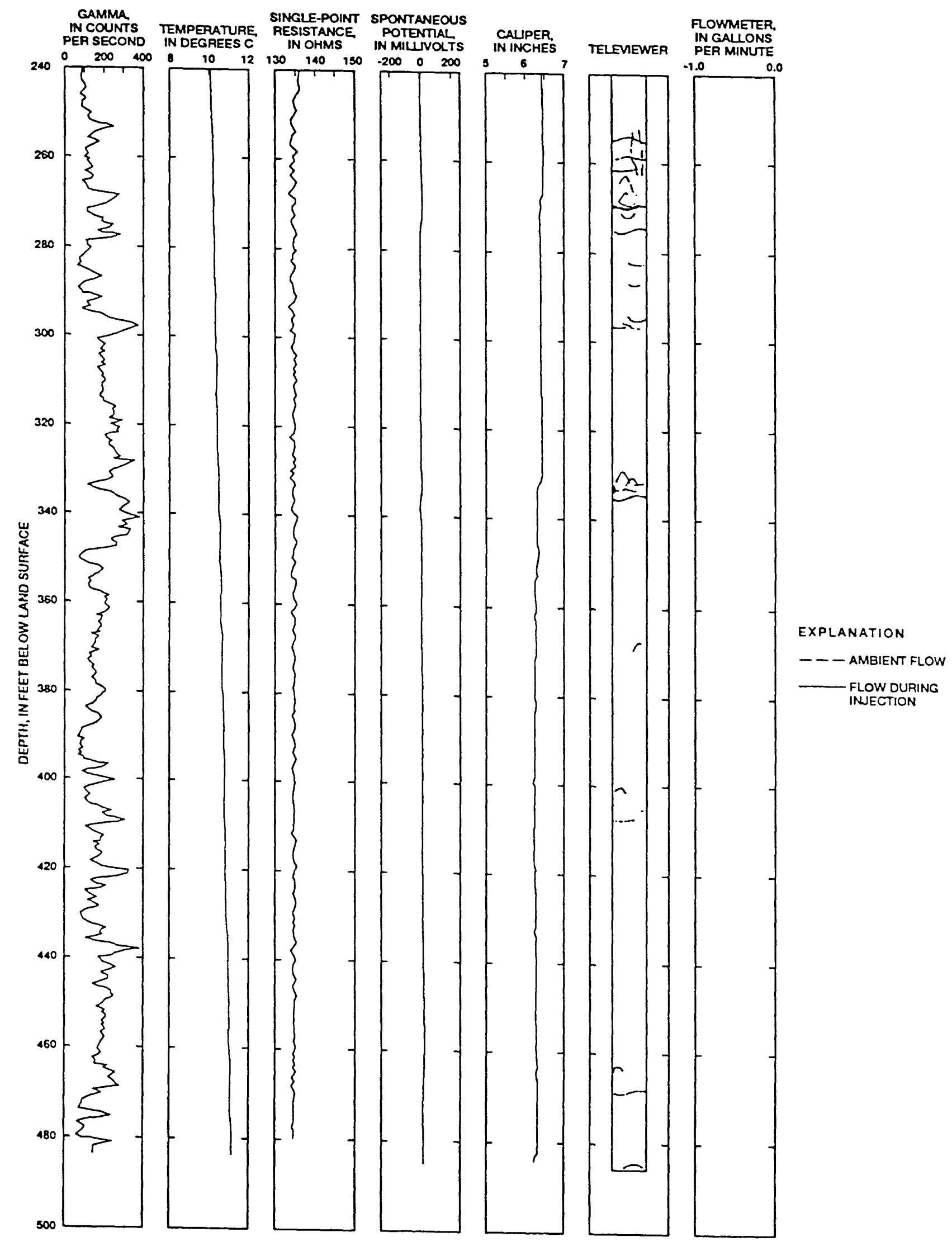

Figure 8. Continued. 


\section{Borehole KR-15A}

The caliper and BHTV logs for borehole KR-15A indicate a number of fractures and fracture zones distributed over the entire depth of the borehole (fig. 9). Many of the fractures and fracture zones indicated on the BHTV log correspond to borehole enlargements evident on the caliper log, and several large fracture zones are intersected by the borehole below $400 \mathrm{ft}$ in depth. The single-point resistance log indicates changes in water quality in the fluid column filling the borehole near 180 and $390 \mathrm{ft}$ in depth.

Naturally occurring downflow under ambient hydraulic-head conditions of about $0.1 \mathrm{gal} / \mathrm{min}$ was detected over the interval from 205 to $465 \mathrm{ft}$ in depth (fig. 9). Inflow occurred at a single fracture near 205 $\mathrm{ft}$ in depth, and outflow occurred in a large fracture zone extending from $455 \mathrm{ft}$ in depth to the bottom of the borehole. During injection tests about $0.7 \mathrm{gal} / \mathrm{min}$ of downflow was induced in borehole KR-15A. About one-third of this flow exited at the fracture near $205 \mathrm{ft}$ in depth associated with inflow under ambient conditions. The other two-thirds of this downflow exited in the large fracture zone below $450 \mathrm{ft}$ in depth. The single-point resistance log is consistent with slightly more saline water entering the borehole at the fracture near $205 \mathrm{ft}$ in depth and exiting near the bottom of the borehole. The second, deeper shift in resistance of the fluid column may be related to a small amount of inflow under ambient conditions and outflow during the injection test that could not be detected with the HPFM. The relatively poor results of the flow normalization (fig. 5) indicate that as much as $0.01 \mathrm{gal} / \mathrm{min}$ outflow could have occurred in the fracture zone near $398 \mathrm{ft}$ in depth without being detected by the HPFM during the injection tests. This small amount of flow could account for the observed shift in the fluid resistance indicated by the single-point resistance log at this depth. 


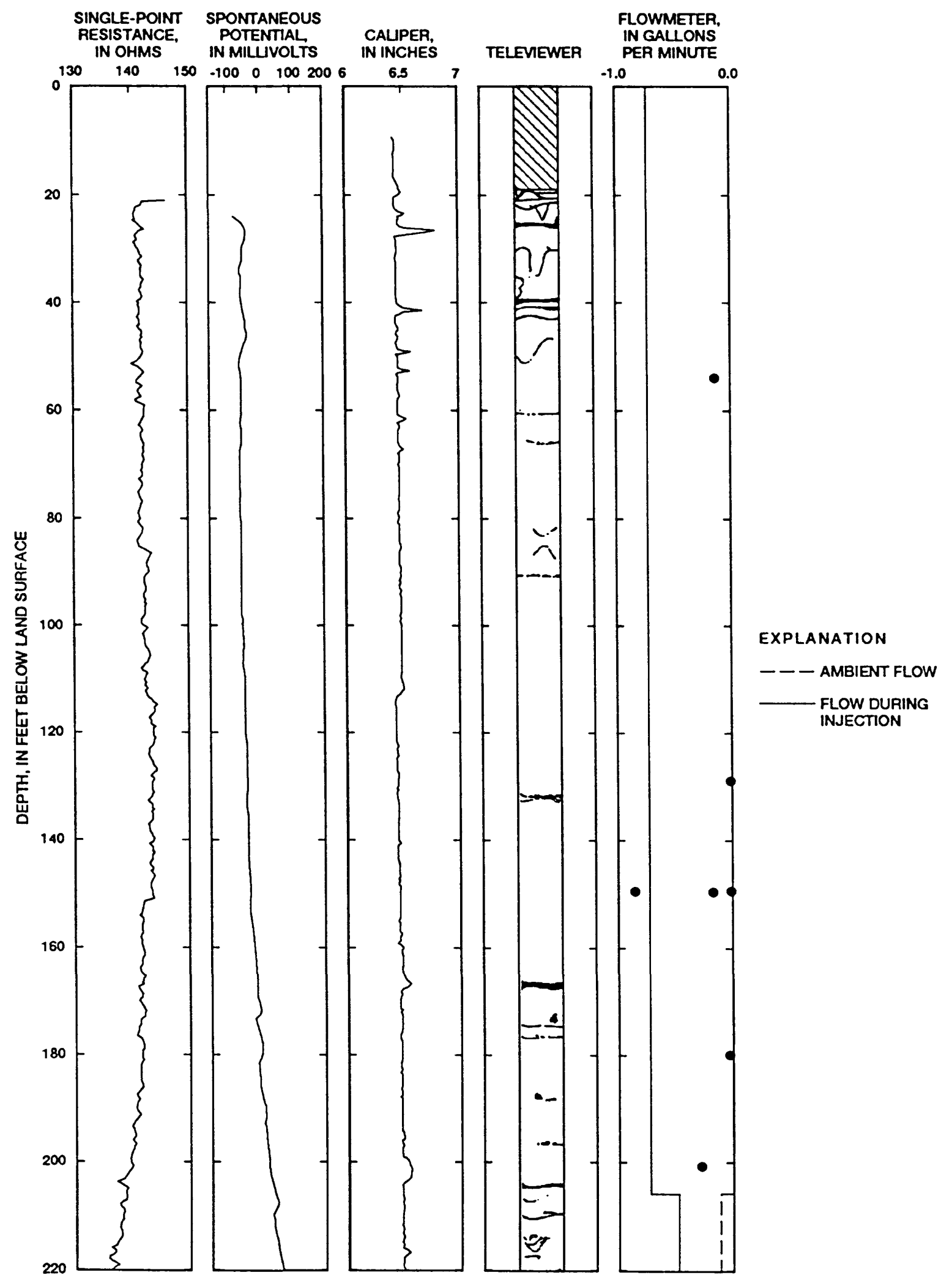

Figure 9. Single-point resistance, spontaneous potential, caliper, borehole televiewer logs and flowmeter logs obtained under ambient hydraulic-head conditions and during injection in borehole KR-15A. 


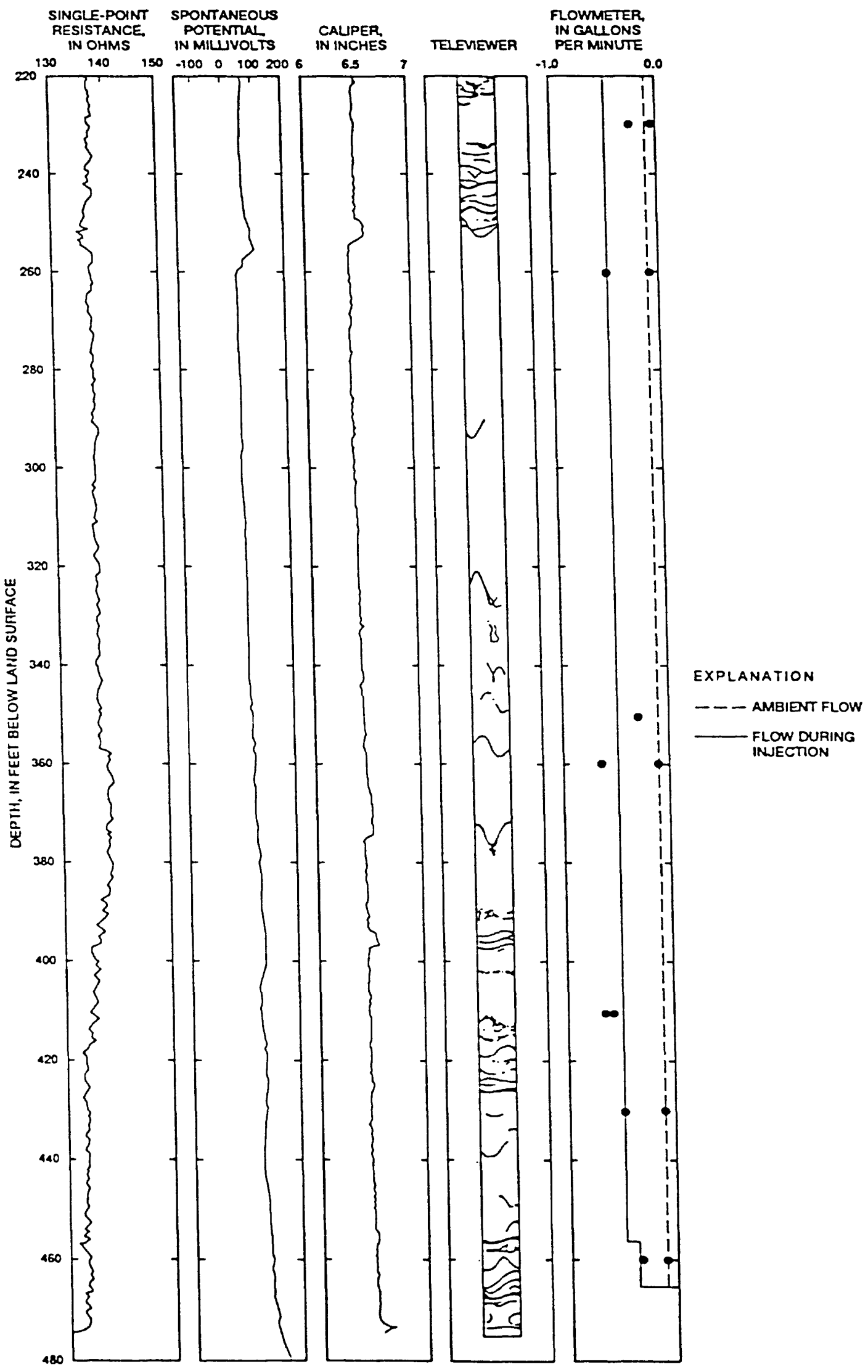

Figure 9. Continued. 


\section{Borehole KR-29}

The caliper and BHTV logs for borehole KR-29 indicate a number of fractures and fracture zones distributed over the entire depth of the borehole (fig. 10). However, only the large fracture zone near the bottom of the borehole is associated with a significant borehole enlargement indicated on the caliper log. The single-point resistance log was not run in this borehole.

Naturally occurring flow under ambient hydraulic-head conditions was measured over almost the entire depth of borehole KR-29 (fig. 10). About 0.1 gal/min entered near the bottom of casing near $28 \mathrm{ft}$ in depth, and an additional $0.1 \mathrm{gal} / \mathrm{min}$ entered at a single, isolated fracture near $57 \mathrm{ft}$ in depth. All of this flow exited in the major fracture zone below $240 \mathrm{ft}$ in depth. 


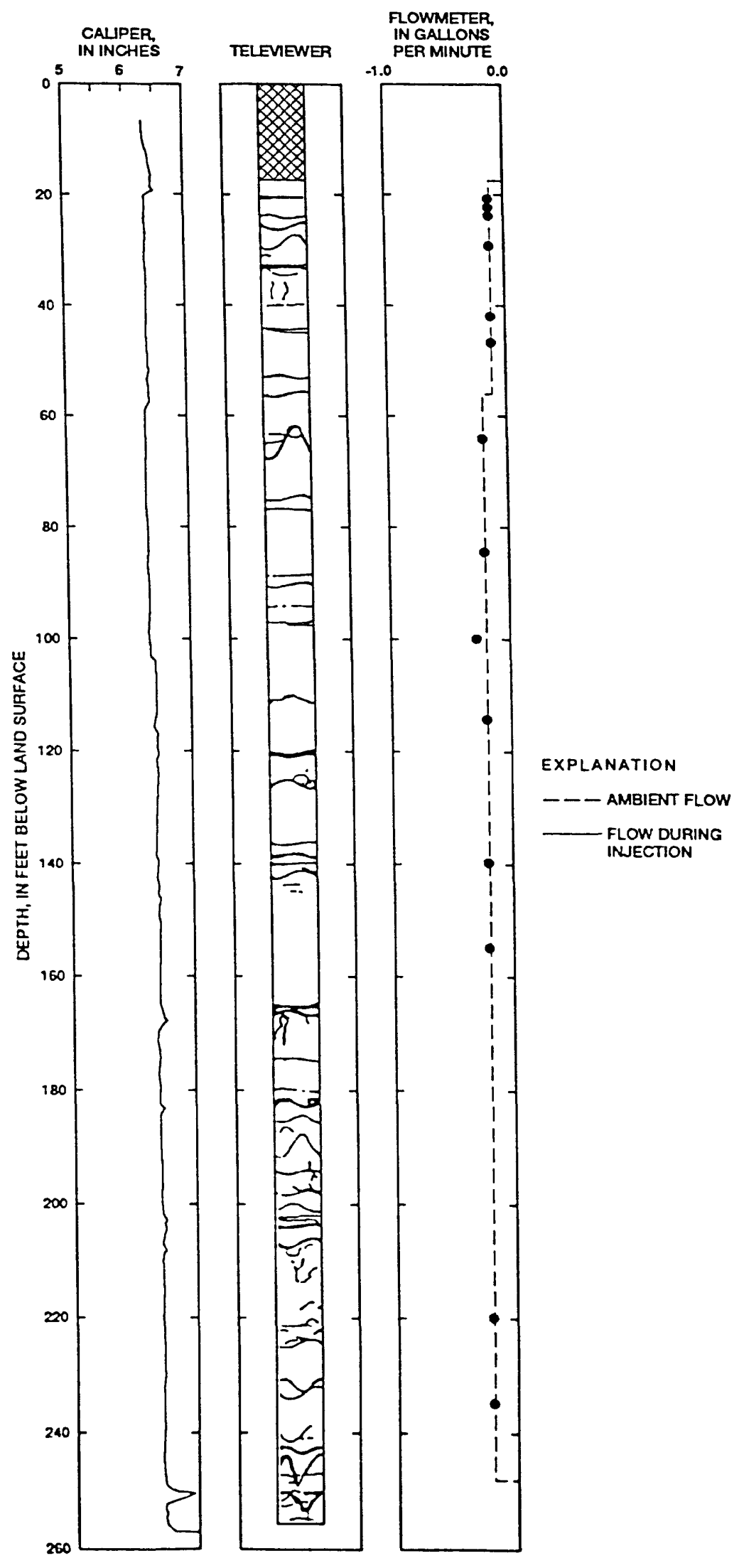

Figure 10. Caliper, acoustic televiewer, and flowmeter logs obtained under anbient hydraulic-head conditions in borehole KR-29. 


\section{Borehole KR-30}

The BHTV log for borehole KR-30 indicates several large fractures above $100 \mathrm{ft}$ in depth; two of these are associated with significant borehole enlargements indicated on the caliper log (fig. 11). The single-point resistance log indicates a constant fluid-column resistance above about $60 \mathrm{ft}$ in depth, a gradual decrease in the interval between 60 and $120 \mathrm{ft}$ in depth, and an abrupt decrease below $120 \mathrm{ft}$ in depth.

Naturally occurring flow under ambient hydraulic-head conditions was not detected in borehole KR30. About $0.3 \mathrm{gal} / \mathrm{min}$ of downflow was induced during the injection test, and all of this flow was found to exit the borehole at a single major fracture or fracture zone near $69 \mathrm{ft}$ in depth (fig. 11). The fluid column resistivity indicated by the single-point resistance log is consistent with weak downflow too small to detect with the HPFM under ambient hydraulic-head conditions. Most of this flow was probably exiting at the fracture near $69 \mathrm{ft}$ in depth, with an even smaller amount of downflow exiting at one or more deeper fractures between 70 and $120 \mathrm{ft}$ in depth. 


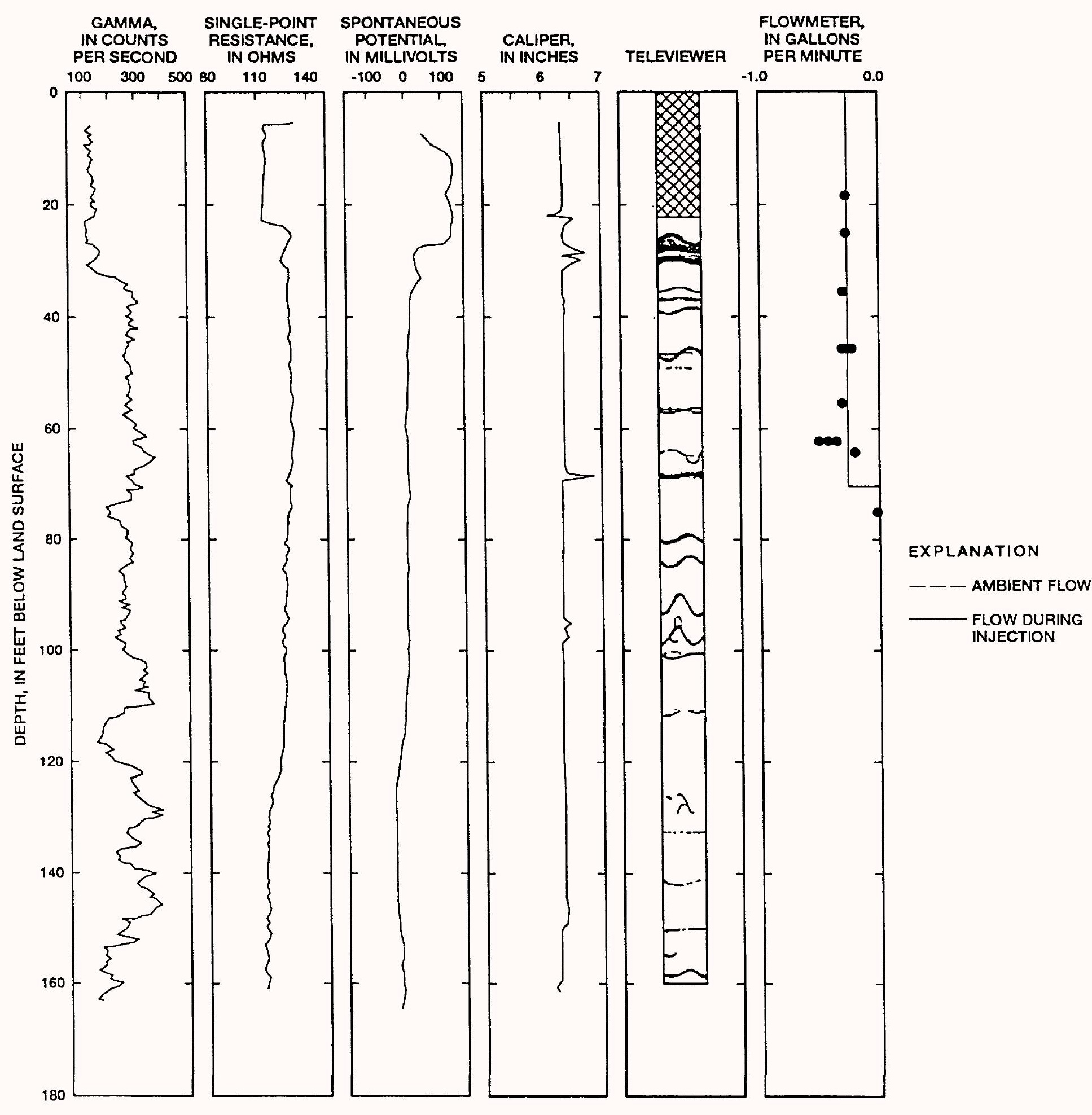

Figure 11. Natural gamma, single-point resistance, spontaneous potential, caliper, acoustic borehole televiewer logs and flowmeter log obtained during injection in borehole KR-30. 


\section{Borehole KR-508}

The caliper and BHTV logs for borehole KR-508 indicate a number of isolated fractures above 200 $\mathrm{ft}$ in depth (fig. 12); BHTV logs were not obtained below a depth of about $200 \mathrm{ft}$ in this borehole. One fracture zone near $170 \mathrm{ft}$ in depth is associated with an especially thick interval of borehole enlargement. The single-point resistance $\log$ indicates a nearly uniform fluid-column resistivity, except for a very weak decrease in resistivity below $240 \mathrm{ft}$ in depth.

Naturally occurring flow under ambient hydraulic-head conditions was not detected in borehole KR508. About $0.2 \mathrm{gal} / \mathrm{min}$ of downflow was induced during the injection test. About one-half of this downflow exited at the large fracture zone near $170 \mathrm{ft}$ in depth; the rest of the downflow exited at one or more fractures between 200 and $230 \mathrm{ft}$ in depth. The fluid-column resistivity indicated by the single-point resistance $\log$ is consistent with very weak downflow under ambient conditions, exiting below $200 \mathrm{ft}$ in depth. 


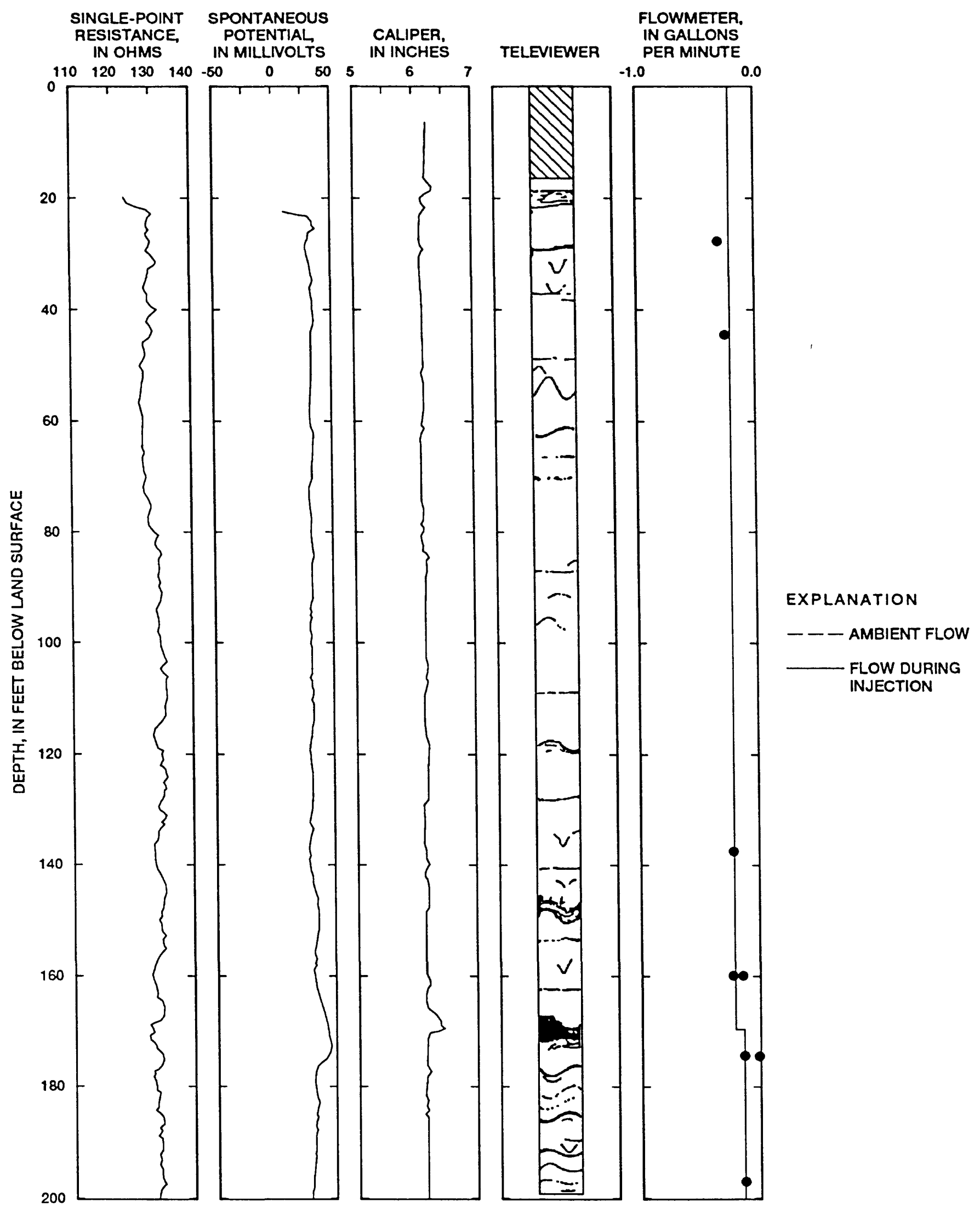

Figure 12. Single-point resistance, spontaneous potential, caliper, and acoustic borehole televiewer logs and flowmeter log obtained during injection in borehole KR-508. 


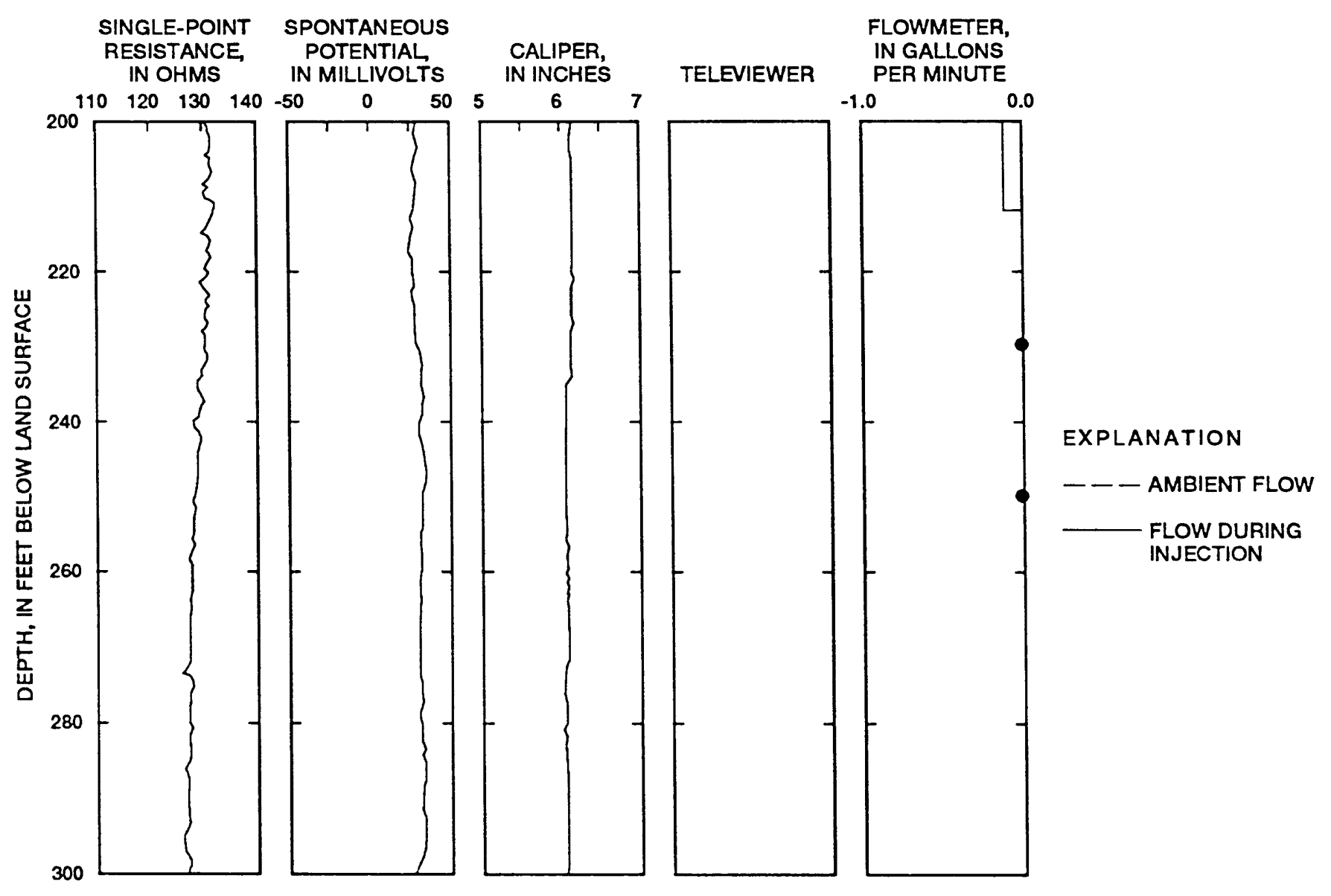

Figure 12. Continued. 


\section{ANALYSIS OF FRACTURE DISTRIBUTIONS AND FRACTURE FLOW AT THE MILLVILLE SITE}

The distribution of fractures and flow in the six Millville boreholes logged for this study (figs. 6-11) provides useful information about the natural movement of ground water in the vicinity of the possible source of contamination adjacent to Kempton Road (fig. 1). This information can be used to make generalizations about the hydraulic properties of the fractured rock aquifer in Millville using the statistical properties of the entire population of fractures indicated on the BHTV logs and the properties of the much more limited set of fractures associated with inflow or outflow under ambient hydraulic-head conditions or during injection tests.

\section{Fracture Distribution}

All of the apparently permeable fractures identified on the BHTV logs obtained in the six Millville boreholes were tabulated according to strike, dip, depth of borehole intersection, and relative size by using the qualitative aperture score previously described in this report. In all, 157 distinct fractures were identified on the BHTV logs. The total number of fractures (distinct points on the polar plot) in figure 13 is less than 157 because parallel fractures plot exactly on top of each other. This effect does not significantly affect the general pattern of the distribution of fracture orientation given by the polar plots in figures 13 and 14, except that the relative percentage of fractures logged as horizontal are underrepresented. Approximately $25 \%$ of all fractures identified on the televiewer logs had dips too small to distinguish from horizontal (dips less than about 20 degrees from horizontal). Twenty-three of these fractures were assigned a score of 3 or greater and are considered to be relatively large fractures. Sixteen fractures were identified as producing inflow or accepting outflow under ambient hydraulic-head conditions or during injection. Only eight of these producing fractures were assigned a score of 3 or greater, so local fracture size at the borehole wall is not closely correlated with local ground-water flow at this site.

In general, the population of fracture planes identified on the BHTV logs do not show any consistent orientation (fig. 13), nor do the subpopulation of those fractures that appear especially large (size scores of 3 or greater, fig. 14) or those associated with inflow or outflow under natural conditions or during injection (fig. 14). The only consistent pattern indicated by the fracture orientations is the lack of poles to fractures in the northwest and southeast quadrants, corresponding to fracture planes dipping steeply to the northwest and southeast (fig. 13). Although 157 fractures appear to be a large population, this number may still not be large enough to provide a statistically significant representation of the properties of a heterogeneous fracture population. Furthermore, many of the fractures identified on the BHTV logs are associated with smaller size interpretation scores. The BHTV log data provide a much smaller population of relatively large fractures. The population of fractures identified on the BHTV logs that are associated with groundwater flow in the HPFM studies is even smaller.

A comparison of the orientations of the fractures identified on the BHTV logs (fig. 13) with those identified on outcrops (fig. 13) shows that the groupings of fractures and joints on the outcrops are not well represented by the televiewer data except for a similar absence of fractures dipping steeply to the northwest and southeast. The outcrop data are represented by concentrations of poles corresponding to sets of steeply dipping joints. Near-vertical boreholes are not likely to intersect a large number of such steeply dipping features. In addition, joints were sampled at the bedrock surface where they are opened by weathering and stress release. The boreholes intersect fractures at depth, where joints may be so tight that they are not detected by the televiewer. The nearly vertical bedrock boreholes and the nearly horizontal, laterally limited surface outcrops probably sample very different populations of bedrock discontinuities. 

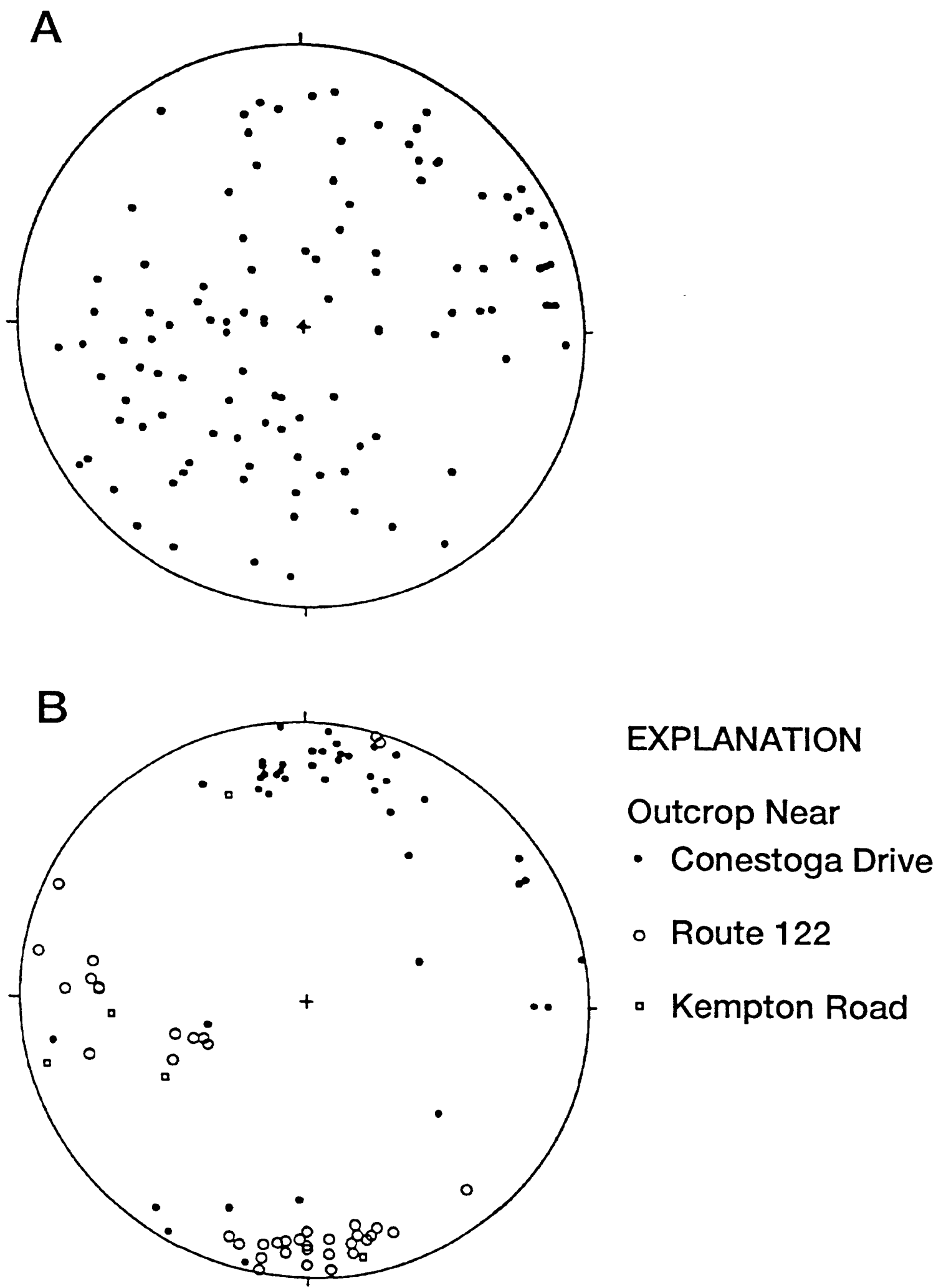

Figure 13. Equal area plots showing (A) poles to all fractures detected on televiewer logs for the Millville boreholes, and (B) poles to joints mapped on surface bedrock exposures at the Millville study site. 

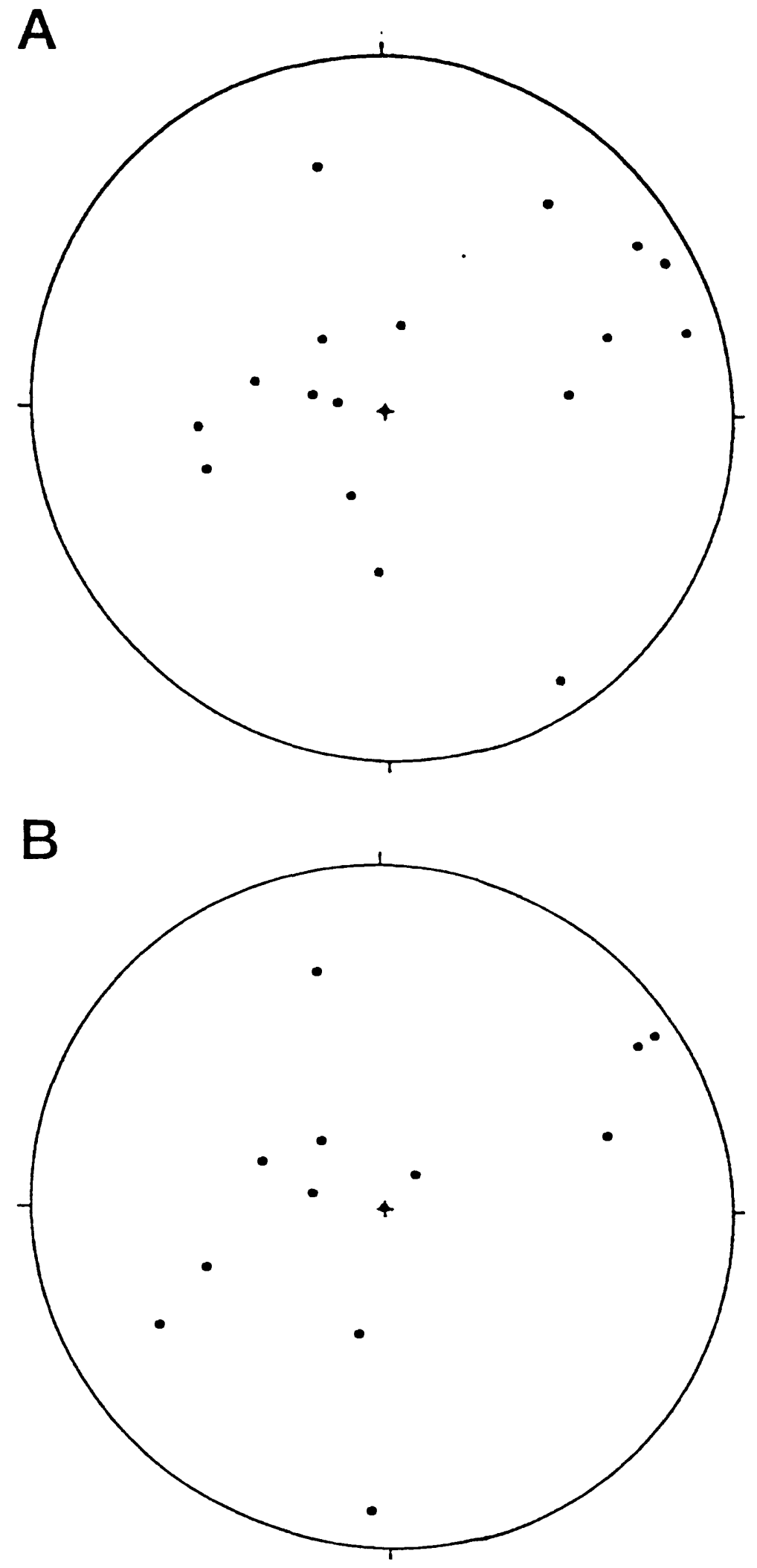

Figure 14. Equal plots showing (A) poles to fractures associated with televiewer size scores greater than 2 , and (B) poles to fractures associated with inflow or outflow under ambient hydraulic-head conditions or during injection tests at the Millville study sitie. 


\section{Fracture Flow}

Although a large number of apparently permeable fractures were intersected by the six boreholes at the Millville site logged as part of this study, the HPFM measurements indicate that only sixteen of these fractures were associated with inflow or outflow under ambient hydraulic-head conditions or with outflow during injection tests. It is even more difficult to draw statistical conclusions from this much smaller population of fractures than from the total population of 157 fractures identified with the BHTV. In addition, many of the depths where outflow was found to occur are associated with fracture zones where the borehole is intersected by several different fractures of different orientations. It is difficult or impossible to identify the specific fracture within these zones that is associated with inflow or outflow. In such situations, the inflow or outflow is assumed to occur through the largest apparent fracture in the interval. It is even possible that the direction of large-scale flow in fracture zones may be along directions associated with the orientation of the zone rather than the orientation of individual fractures within the zone. Such large-scale flow directions cannot be inferred from the orientations of specific fractures intersecting a single borehole (Paillet and others, 1987a). Within these limitations, several general conclusions may be drawn about the characteristics of fractures conducting flow in the rock mass adjacent to the Millville boreholes. Most of the producing fractures identified with the BHTV and HPFM measurements appear as relatively large and permeable fractures or fracture zones on the BHTV log. However, many other apparently nonpermeable fractures and fracture zones appear just as large on the BHTV log. These results do not refute the conclusion that many of the fractures on the BHTV log are locally permeable. Instead, results indicate that only a small proportion of the fractures identified as locally permeable adjacent to the borehole are connected to the larger scale fracture flow system. These results are consistent with studies showing that fracture connectivity is as important as local fracture aperture in determining the patterns of flow through a fracture rock aquifer (Long and others, 1982).

The results from the fracture flow logging at the Millville site are not sufficient to completely define the flow in the bedrock; they do, however, provide some information about the possible transport of contaminants. All of the data indicate that there is naturally occurring downflow within the rock mass. This downward flow could be an important mechanism by which contaminants enter the deeper aquifer. This mechanism explanation appears likely for contaminated wells located at more than a few hundred feet from the surface soil contamination, where transport through shallow fractures would not be likely. It is also possible that contaminants identified in some of the former water-supply wells may have entered the borehole through shallow fractures under ambient hydraulic-head conditions rather than through deeper, more productive fractures during pumping. At the same time, the measured contaminants could be representative of water in the deeper aquifer because water samples obtained from an open borehole would not indicate the specific depth interval where the sampled water entered the borehole. Fracture zone isolation and testing of water samples obtained from individual fracture zones was needed to determine the concentrations of contaminants in water entering boreholes through the inflow and outflow zones identified in this study.

All of the data obtained at the Millville site indicated that there was downflow under ambient hydraulic-head conditions in all boreholes. Significant downflow was measured in three of the six boreholes logged as part of this study; fluid column logs indicated that downflows smaller than the 0.02 gal/ min flow resolution of the heat-pulse flowmeter may have been present in the other three boreholes at the time of logging. These results are consistent with the location of the study site on a topographic high, indicating regional downflow associated with recharge conditions, which probably is augmented by withdrawal of water from the aquifer by water-supply wells. The downwardly decreasing hydraulic heads inferred from the measured downflows and the distribution of water-producing fractures identified in the six boreholes logged during this study indicate that the fractured bedrock aquifer can be separated into upper and lower fracture zones (fig. 2). The upper fracture zone would contain fractures projecting to the bedrock surface in the vicinity of the suspected source of contamination. The lower fracture zone would contain fractures not likely to project to the bedrock surface near the suspected contamination source. Any 
contaminant entering boreholes through the lower fracture zone would have entered those deeper fractures by means of steeply dipping fractures not likely to be sampled by vertical boreholes.

The magnitude of the differences in hydraulic head between the upper and lower fracture zones in some of the Millville boreholes was investigated by installing packers at depths corresponding to an elevation of $350 \mathrm{ft}$ in boreholes KR-2, KR-508, and KR-29. The static water levels below the packers in boreholes KR-2 and KR-29 remained close to those measured in these boreholes before installation of packers, while the water levels measured above the packers in the boreholes rose about $10 \mathrm{ft}$ above the previous open-hole water levels. These results confirm the downwardly decreasing hydraulic-head distribution in the aquifer. They also show that the water levels in boreholes KR-2 and KR-29 were controlled by the lower fracture zone before packer installation, indicating that the fractures in the lower fracture zone are much more permeable than those in the upper fracture zone in the vicinity of these boreholes. The changes in water levels above and below the packer installed in borehole KR-508 indicated that there was about the same 10-ft difference in hydraulic head between the upper and lower fracture zones. However, most of the change in measured water levels occurred in the interval below the packer, indicating that the water level in borehole KR-508 had been controlled by the upper fracture zone before installation of the packer. Therefore, the upper fracture zone is more permeable than the lower fracture zone in the immediate vicinity of borehole KR-508. These results are important because they indicate that most inflow to boreholes KR-2 and KR-29 occurred from the deeper interval during pumping. The results for KR-508 are less certain because they appear inconsistent with results obtained during flowmeter logging where injected water exited the borehole below the packer depth. These results are consistent only if the relative permeabilities of the upper and lower zone fractures differ depending on flow rates. This might be caused by differences in the extent and connectivity of the permeable fractures intersecting the well in each zone. Apparently, at low flow rates the upper zone fractures supply enough water to control water levels in the well. However, the upper level fractures were incapable of accepting significant flow at higher flow rates during injection test. Based on these observations, pumping might result in greater water production from deeper zones than would be predicted by the observations of water levels before and after installation of the packer.

Water samples were obtained from four of the boreholes logged as part of this study by sampling the fluid column at a depth interval characterized by downflow within the borehole. Therefore, the water sampled would have entered the borehole through fractures identified as supplying inflow under ambient hydraulic-head conditions. The contaminant concentrations in these samples may be compared to the concentrations in samples obtained when the same four boreholes were being used as water-supply wells in July 1991 (table 1). Samples obtained about a year after these boreholes were abandoned as watersupply wells (July 1992) show a decrease in contaminant concentrations in three of the four boreholes (boreholes KR-2, KR-508, and KR-15A) and about the same concentrations or perhaps a slight increase in the other borehole (borehole KR-29). These changes in concentrations are attributed to the changes in the pattern of flow associated with the removal of a number of bedrock wells from use at the Millville site. When water samples are taken from the "tap" in active water-supply systems, the sampled water is derived from the most permeable fractures intersecting the borehole. When water samples are taken from the fluid column in the borehole after pumping has been discontinued, the samples are derived from the fractures serving as the source of inflow under ambient hydraulic-head conditions. 
Table 1. Tetrachloroethene (PCE), trichloroethene (TCE), and 1, 1, 1-trichloroethane (TCA) concentrations in private water-supply wells exhibiting downflow under ambient hydraulic-head conditions.

[ $\mu \mathrm{g} / \mathrm{L}$, microgram per liter; data from HMM Associates, Inc. (written commun., 1993)]

\begin{tabular}{lcccc}
\hline Well number and iocation & Date sampled & $\begin{array}{c}\text { PCE } \\
(\mu g / \text { ) }\end{array}$ & $\begin{array}{c}\text { TCE } \\
(\mu g / \text { ) }\end{array}$ & $\begin{array}{r}\text { TCA } \\
(\mu g / \text { ) }\end{array}$ \\
\hline KR-2 & $7 / 91$ & 21,000 & 13,000 & 16,000 \\
115 Kempton Road & $7 / 92$ & 16,000 & 5,200 & 5,800 \\
& $7 / 91$ & 36,000 & 43,000 & 29,000 \\
KR-508 & $7 / 92$ & 15,000 & 1,600 & 11,000 \\
508 Kempton Road & $7 / 91$ & & & \\
& $7 / 92$ & 11,000 & 16,000 & 17,000 \\
KR-29 & & 16,000 & 20,000 & 16,000 \\
Lot 29 Conestoga Drive & $7 / 91$ & & & 96 \\
& $7 / 92$ & 1,800 & 1,600 & 5 \\
\hline KR-15A & 21 & 26 & \\
\hline
\end{tabular}

In general, contaminants can enter bedrock boreholes from a shallow source directly through shallow fractures or indirectly through deeper fractures. If a contaminant migrates to the sampling point through deeper fractures, the fractures where the contaminant enters the borehole during pumping are connected to the original surface source of contamination by means of other, steeply dipping or vertical fractures that were not indicated by the borehole logs. These relationships are further complicated at the Millville site because immiscible liquid contaminants may have entered bedrock fractures. If such is the case, denser than water, non-aqueous liquids may be acting as continuing sources of dissolved contamination within the bedrock aquifer. This possibility does not effect conclusions regarding simple or complex contaminant migration pathways, but is important in considering possible locations of continuing sources of dissolved contaminants.

The changes in water level observed in boreholes KR-2 and KR-29 after installation of packers to separate upper and lower fracture zones provide some insight into whether contaminants entered boreholes directly through fractures in the upper part of the borehole or indirectly through deeper fractures connected to a more tortuous pathway for contaminant transport. Boreholes KR-2 and KR-29, where the response of water levels after installation indicated inflow was derived from the deeper fractures, were associated with both a decrease (borehole KR-2) and an increase (borehole KR-29) in contaminant concentrations after pumping stopped. In a third borehole (borehole KR-508) where flowmeter and water level data disagree, the flowmeter data which indicates that lower fracture zone fractures are more permeable most easily explains the decrease in contaminant concentrations after pumping stopped. The two boreholes which exhibited decreases in contaminant concentrations (boreholes KR-2 and KR508) are located up-gradient and cross-gradient from the contaminated soils relative to groundwater flow directions in the surficial aquifer. The only well showing an increase in contaminant concentrations after pumping stopped 
is located downgradient of the contaminated soils underneath a plume of contaminated groundwater in the overburden aquifer. On the basis of these results, the transport of contaminants towards the boreholes logged at the Millville site occurred both directly through shallow fractures (the upper fracture zone in figure 2), and indirectly through more complex fracture connections allowing contaminants to migrate from the surficial source to deeper fractures (the lower fracture zone in figure 2).

\section{SUMMARY}

A suite of geophysical logs designed to characterize fractures and their water-yielding capacity where they intersect boreholes was run in six bedrock boreholes at a ground-water contamination site near Millville in south-central Massachusetts. The following geophysical logs were used in this study: gamma, conventional single-point resistance, borehole fluid resistivity, caliper, spontaneous potential, temperature, borehole televiewer, and heat-pulse flowmeter. The flowmeter measured downward flow in three of the boreholes at the site, and the profile of fluid-column resistivity inferred from the single-point resistance logs indicates downward flow in all six boreholes. Steady injection tests at about 1.0 gallon per minute were used to identify fractures capable of conducting flow under increased hydraulic-head conditions. All of the intervals in each of the boreholes identified with inflow under ambient conditions or during injection contained at least one fracture that was interpreted as permeable in the vicinity of the borehole on the basis of televiewer log analyses. However, many other similar fractures did not appear to conduct flow under ambient or test conditions. These results demonstrate that fractures that probably are permeable within the immediate vicinity of the borehole need to be connected to larger scale flow paths in order to contribute to the flow.

In all, 157 apparently permeable fractures were identified on the televiewer logs. Twenty-three of these fractures were determined to be relatively large in comparison with the typical appearance of fractures on televiewer image logs. Sixteen of the fractures identified on the televiewer logs were determined to conduct flow under ambient hydraulic head conditions or during injection, but only eight of these producing fractures are included in the set of 23 large fractures that appeared to have the largest hydraulic apertures in the immediate vicinity of the borehole.

Hydraulic-head monitoring in the bedrock boreholes indicated a consistent head difference between the upper and lower parts of the boreholes. This difference was about $10 \mathrm{ft}$ during the monitoring period and accounts for the observed downward flow in the six boreholes during logging. This naturally occurring hydraulic-head condition may account for the transport of contaminants from the surficial deposits into the bedrock aquifer. The downward flow may also account for the decrease in contaminant found in some boreholes after routine use of the boreholes as water-supply wells was discontinued because the discontinuance of pumping changed hydraulic conditions in the borehole from periodically induced upflow to continuous downward flow.

\section{REFERENCES}

Goldsmith, Richard, 1991, Structural and metamorphic history of eastern Massachusetts, in Hatch, N.L., ed., The bedrock

geology of Massachusetts: U.S. Geological Survey Professional Paper 1366-H, p. H1-H63.

Hess, A.E., 1986, Identifying hydraulically conductive fractures with a low-velocity borehole flowmeter: Canadian Geotechnical Journal, v. 23, no. 1, p. 69-78.

Hess, A.E., and Paillet F.L., 1990, Applications of the thermal-pulse flowmeter in the hydraulic characterization of fractured rocks, in F.L. Paillet and W.R. Saunders, eds., Geophysical Applications for Geotechnical Investigations: American

Society Testing Materials STP 1101, p. 99-112.

HMM Associates, Inc., 1993, Site investigation report, Kempton Road Site, Millville, Massachusetts, prepared for Commonwealth of Massachusetts, Executive Office of Environmental Affairs, Department of Environmental Protection, Bureau of Waste Site Cleanup. 
Keys, W.S., 1979, Borehole geophysics in igneous and metamorphic rocks, in Society of Professional Well Log Analysts Annual Logging Symposium, 20th, Tulsa, Okla., 1979, Transactions: Houston, Tex., Society of Professional Well Log Analysts, p. 001-26.

1991, Borehole geophysics applied to ground-water investigations: U.S. Geological Survey Techniques of WaterResources Investigations, book 2, chap. E2, $150 \mathrm{p}$.

Long, J.C.S., Remer, J.S., Wilson, C.R., and Witherspoon, P.A., 1982, Porous media equivalents for networks of discontinuous fractures: Water Resources Research, v. 18, p. 645-658.

McKniff, J.M., 1964, The petrology of the southern half of the Blackstone quadrangle, Massachusetts and Rhode Island: Providence, R.I., Brown University, Master's thesis, 37 p.

Paillet, F.L., 1991, Use of geophysical well logs in evaluating crystalline rocks for siting of radioactive-waste repositories: The Log Analyst, v. 33, no. 2, p. 85-107.

Paillet, F.L., and Kapucu, Kemal, 1989, Fracture characterization and fracture-permeability estimates from geophysical logs in the Mirror Lake watershed, New Hampshire: U.S. Geological Survey Water-Resources Investigations Report 89$4058,49 \mathrm{p}$.

Paillet, F.L., Keys, W.S., and Hess, A.E., 1985, Effects of lithology on televiewer log quality and fracture interpretation, in Society of Professional Well Log Analysts Annual Logging Symposium, 26th, Dallas, Tex., 1985, Transactions: Houston, Tex., Society of Professional Well Log Analysts, p. JJJ1-JJJ31.

Paillet, F.L., Hess, A.E., Cheng, C.H., and Hardin, E.L., 1987a, Characterization of fracture permeability with high-resolution vertical flow measurements during pumping: Ground Water, v. 25, no. 1, p. 28-40.

Paillet, F.L., Hsieh, Paul, and Cheng, C.H., 1987b, Verification of acoustic waveform and seismic VSP measurement of fracture permeability, in Society of Professional Well Log Analysts, 28th, London, England, 1987, Transactions: Houston, Tex., Society of Professional Well Log Analysts, p. PP1-PP21.

Paillet, F.L., Barton, Colleen, Luthi, Stefan, Rambow, Fritz, and Zemanek, Joseph, eds., 1990, Society of Professional Well Log Analysts Borehole Imaging Volume: Houston, Tex., Society of Professional Well Log Analysts, 472 p.

Zemanek, Joseph, Glenn, E.E., Norton, L.J., and Caldwell, R.L., 1970, Formation evaluation by inspection with the borehole televiewer: Geophysics, v. 35, no. 2, p. 254-269.

Zen, E-an, [ed.], Goldsmith, Richard, Ratcliff, N.L., Robinson, Peter, and Stanley, R.S., [compilers], 1983, Bedrock geologic map of Massachusetts: U.S. Geological Survey, Washington, D.C., 3 sheets, scale 1:250,000. 